\title{
Understanding the Political Challenge of Red and Processed Meat Reduction for Healthy and Sustainable Food Systems: A Narrative Review of the Literature
}

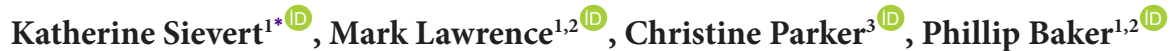

\begin{abstract}
Background: Diets high in red and processed meat (RPM) contribute substantially to environmental degradation, greenhouse gas (GHG) emissions, and the global burden of chronic disease. Recent high-profile reports from international expert bodies have called for a significant reduction in global dietary meat intake, particularly RPM, especially in high-income settings, while acknowledging the importance of animal-sourced foods to population nutrition in many lower-income countries. However, this presents a major yet under-investigated political challenge given strong cultural preferences for meat and the economic importance and power of the meat industry.

Methods: A theoretically-guided narrative review was undertaken. The theoretical framework used to guide the review considered the interests, ideas and institutions that constitute food systems in relation to meat reduction; and the instrumental, discursive and structural forms of power that actors deploy in relation to others within the food system. Results: High production and consumption levels of RPM are promoted and sustained by a number of factors. Actors with an interest in RPM included business and industry groups, governments, intergovernmental organisations, and civil society. Asymmetries of power between these actors exist, with institutional barriers recognised in the form of government-industry dependence, trade agreement conflicts, and policy incoherence. Industry lobbying, shaping of evidence and knowledge, and highly concentrated markets are key issues. Furthermore, prevailing ideologies like carnism and neoliberalism present embedded difficulties for RPM reduction. The literature noted the power of actors to resist meat reduction efforts exists in varying forms, including the use of lobbying, shaping of evidence and knowledge, and highly concentrated markets.

Conclusion: There are a number of political challenges related to RPM reduction that contribute to policy inertia, and hence are likely to impede the transformation of food systems. Research on policy efforts to reduce RPM production and consumption should incorporate the role of power and political feasibility.

Keywords: Red Meat, Processed Meat, Political Challenge, Environmental Sustainability, Food Systems

Copyright: $\odot 2021$ The Author(s); Published by Kerman University of Medical Sciences. This is an open-access article distributed under the terms of the Creative Commons Attribution License (https://creativecommons.org/licenses/ by/4.0), which permits unrestricted use, distribution, and reproduction in any medium, provided the original work is properly cited.

Citation: Sievert K, Lawrence M, Parker C, Baker P. Understanding the political challenge of red and processed meat reduction for healthy and sustainable food systems: a narrative review of the literature. Int $J$ Health Policy Manag. 2021;10(12):793-808. doi:10.34172/ijhpm.2020.238
\end{abstract}

Article History:

Received: 29 May 2020 Accepted: 18 November 2020 ePublished: 2 December 2020

View Video Summary

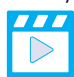

*Correspondence to:

Katherine Sievert

Email: k.sievert@deakin.edu.au

\section{Background}

Unhealthy diets and poor nutrition together are the leading contributors to the global burden of disease. ${ }^{1}$ Diet-related chronic diseases including cardiovascular disease, cancers and type-2 diabetes are prominent causes of death and disability, ${ }^{2}$ and contribute substantially to current and future health-related government expenditures. ${ }^{3}$ Diets high in red and processed meats (RPMs) are significant contributors to this disease burden. ${ }^{4}$

The World Health Organization (WHO) defines 'red meat' as any mammalian meat (beef, veal, pork, lamb, mutton, horse, or goat), usually consumed cooked, and 'processed meat' as any meat that has been changed (eg, by salting, curing, fermentation, smoking) to augment flavour or improve preservation. ${ }^{5}$ Red meat is a source of essential macro- and micro-nutrients, such as protein, iron and vitamin $\mathrm{B} 12,{ }^{6}$ although with the exception of $\mathrm{B} 12$, these nutrients are also in plant-based foods, albeit in less bioavailable form. ${ }^{7}$ However, processed and red meats have also been classified as carcinogens by WHO's International Agency for Research on Cancer (IARC). ${ }^{8}$ The consumption of RPM has been associated with colorectal cancer in longitudinal studies, and there is emerging evidence of associations with cancers of the stomach, pancreas, prostate, lung, and breast. ${ }^{8,9}$ It is not fully understood how cancer risk increases with RPM consumption, however there is speculation that carcinogens, in particular heterocyclic amines, can form during processing or cooking at high temperatures. ${ }^{10,11}$ Furthermore, haem iron, found in high amounts in red meat, may promote colorectal tumour growth. ${ }^{12} \mathrm{RPM}$ reduction is not considered advisable or necessary in low- and middle-income countries where intake is generally low, ${ }^{13,14}$ and food scarcity and lack of access to food may prevent adequate nutrient intake. Although moderate amounts of red meat can be an important 
component of a healthy diet, dietary guidelines in most highincome countries advise limiting consumption of red meat and avoiding processed meats altogether.

RPM production also generates environmental harms. Livestock production contributes an estimated $14 \%-30 \%$ of all human-made greenhouse gas (GHG) emissions, ${ }^{15,16}$ and is the largest source of anthropogenic methane emissions. RPM production also requires a disproportionate amount of land and finite resources relative to other foods. ${ }^{17}$ Some forms of cattle production for example, require up to $25 \mathrm{~kg}$ of animal feed and $15000 \mathrm{~L}$ of water to produce $1 \mathrm{~kg}$ of beef. ${ }^{18,19}$ As demand for RPM rises, there is increasing pressure to use intensive farming practices such as feedlots rather than pastoral grazing. This increases the demand for animal feed, mostly from intensively mono-cropped grain crops such as corn and soy, which contributes to deforestation in places like the Amazon. ${ }^{21}$

With the exception of pork, RPM consumption is marginally declining in many high-income countries such as Australia and the United States, ${ }^{22}$ and plateauing in others. ${ }^{23}$ Despite this declining trend, per capita RPM consumption in high-income countries is three times higher than the global average. Middle-income countries are experiencing rapid increases in per capita meat consumption, ${ }^{24,25}$ associated with income and population growth, increasing urbanisation, and increased international trade - characteristics of the nutrition transition. ${ }^{26}$ Many high-income countries play a large role in the production and export of RPM. ${ }^{27}$ The increasing worldwide output is estimated to lead to GHG emissions from meat production rising by as much as $80 \%$ by $2050,{ }^{28}$ exacerbating the effects of climate change. The anticipated impact of climate change on human health includes increased exposure to extreme weather events, infectious diseases, poor mental health, heat-related illnesses, and food insecurity. ${ }^{29}$ Furthermore, intensive meat production contributes to future risks of antibiotic resistance and pandemics with zoonotic origins, such as H1N1 influenza and more recently, severe acute respiratory syndrome coronavirus 2 (SARS-CoV-2). ${ }^{30}$

Acknowledging the associated harms, many authoritative bodies have called for systemic meat reduction for healthy and sustainable food systems. We use the term 'meat reduction' to refer to systematic efforts, involving actions throughout the food system, to reduce the production, marketing and consumption of RPM. The Intergovernmental Panel on Climate Change (IPCC) has called for a global food systems response including major dietary change and reductions in meat production and consumption as one component in maintaining global anthropogenic warming under $2{ }^{\circ} \mathrm{C} .{ }^{31} \mathrm{~A}$ recent high-profile report by the EAT Lancet Commission on Food, Planet and Health ("The Commission") ${ }^{32}$ also called for limited consumption and production of RPM as a key strategy to mitigate the negative effects of modern industrial food systems on both population health and the environment. Shifting to healthy and sustainable diets, including reducing meat consumption, would prevent an estimated 10.9 to 11.6 million deaths per year, reduce GHG emissions, help protect environmental biodiversity, and reduce competition for water and other natural resources. ${ }^{32}$ The Commission proposed a package of food systems policy interventions to achieve its ambitious dietary targets. These include international and governmental support to regulate trade, remove farming and agricultural subsidies for meat and feedstock, attenuate livestock production, strengthen environmental governance, and target consumer behaviour change. ${ }^{32}$ Effective policy action to reduce RPM would require a synergistic package of strategies that work at multiple points to address the range of actors and interests, ideas and institutions that currently support a political economy of high RPM production and consumption. ${ }^{33,34}$

Despite calls for action from various international authoritative bodies, there is marked disagreement on the nature of the RPM problem, the optimal degree of reduction, and the best ways to address RPM-related harms. ${ }^{35,36}$ Meat has been a divisive topic in the media and among policymakers, with often conflicting interpretations regarding the associated health and environmental harms, and different views about which, if any, policy actions should be taken. Recent proposals in both the United Kingdom and Australia for a meat tax, for example, were met with strong objections in public discourse. ${ }^{37,38}$ Many advocate for integrated policy approaches to achieve healthy and sustainable food systems, through actions targeting multiple leverage points throughout the food system simultaneously. ${ }^{35,36,39}$ However, potential reduction efforts can be obstructed or limited by powerful actors in food systems, and the discursive and institutional frameworks currently shaping food policy priorities and guiding system-wide action. Meat production and processing industries in particular are major contributors to rural livelihoods and the economy of many countries, ${ }^{40}$ and involve a number of organised interest groups that have an interest in using their power to maintain the status quo and undermine efforts at RPM reduction.

RPM reduction presents an important, yet underinvestigated, challenge to achieving the policies outlined by the Commission, IPCC and WHO. Strategies for transitioning to healthy and sustainable food systems will be vital in coming years, including actions to mitigate the harms linked with RPM. Despite research into potential approaches and policy actions for reducing RPM, such as meat taxes or consumer labelling (see Supplementary file 1 for a full outline of proposed policy actions to attenuate meat production and consumption), there is little scholarly investigation of the political feasibility of these actions in light of the contested nature of meat reduction. Acknowledging these challenges, the aim of this review is to identify and understand the key political economy challenges of reducing the production and consumption of RPM, in order to inform societal actions towards healthy and sustainable food systems.

\section{Methods}

This study used a narrative literature review and synthesis method. ${ }^{41}$ This involved a scholarly summary of evidence incorporating author interpretation and critical analysis. ${ }^{42}$ It is appropriate for the study aim as it allows for the exploration of relationships within and between studies on a complex topic, as well thematic analysis of key findings. This method 
also allows for both amalgamation and analysis of a broad range of studies that fall under a variety of disciplines and formats. This is important as the topic has been investigated by a wide range of academic disciplines and organisations. The method involved four steps: (1) exposition of theory to guide both the search and the analysis; (2) a systematic search for relevant literature, with additional branching searches where necessary; (3) analysis of the literature sources and identification of key themes, and (4) thematic synthesis of the results. To strengthen the rigour of the review process, these steps were guided by the Preferred Reporting Items for Systematic reviews and Meta-Analyses (PRISMA) guidelines. $^{43}$

\section{Theoretical Framework}

To guide the review, we adopted a theoretical approach grounded in political economy. This means examining 'political, economic and social forces in society, the distribution of power and resources between different actors within and surrounding food systems, and the processes that generate, sustain and transform these relationships over time. ${ }^{39,44,45}$ This approach involves understanding the power of actors to shape various elements of food systems including production inputs, supply chains, food environments and consumer behaviour, as well as the policy, regulatory and knowledge frameworks that define those systems. ${ }^{46,47}$ To do this, we adopted two key frameworks. First, the 'Three I's' framework to consider how the Interests, Ideas, and Institutions that constitute food systems can resist or promote meat reduction. Second, was Clapp and Fuchs' tripartite framework to understand how the instrumental, discursive, and/or structural power of actors influences these interests, ideas and institutions..$^{20,50,51}$

\section{The 3 I's: Interests, Ideas, and Institutions}

A first step in political economy analysis is 'actor designation' - the identification of individuals, organisations, and groups who have an interest in meat reduction, and who deploy and accrue power within the system. ${ }^{52}$ Many actors have an interest in meat reduction, including intergovernmental organisations, governments, civil society groups, businesses, scientists and consumers. The interests of these actors in relation to meat reduction varies, including private interests (such as maintaining corporate profits), public interest (such as promoting health, reducing healthcare costs, and protecting the environment), or both (such as economic growth). These interests are often upheld and sustained by cultural variables or socially-constructed beliefs, referred to as ideas. ${ }^{48}$ Ideas refer to shared values, beliefs, assumptions and forms of knowledge about the nature of reality, that guide decision-making and behaviour. ${ }^{53-55}$ In the policy arena, ideas are constructed and upheld via the 'coordinative discourses' of multiple actors connected to an issue, including networks of experts, civil society advocates, business associations, and politicians among others, who share common interests and causal beliefs, such as whether and to what extent RPM is a problem, what causes the problem, and what solutions should be prioritised. ${ }^{48,56}$ Ideas that dominate within political and policy-making systems can come to define and constitute institutions, as the "formal and informal rules, norms, precedents, and organisational factors that structure political behaviour" ${ }^{27}$ (p. 709, referencing $\mathrm{Hall}^{48}$ ). Institutions often, in turn, act as ideational filters by legitimising certain forms of knowledge and evidence over others. ${ }^{58}$ Institutions can include, for example, government policy-making processes, governance structures, laws and regulations, dominant norms within policy-making organizations or in society-atlarge, and historical relationships between political decisionmakers and other societal elites such as business leaders. ${ }^{59,60}$

\section{Instrumental, Discursive, and Structural Power Framework} In order to understand the power of actors to influence the interests, ideas and institutions that constitute food systems in ways that resist or promote meat reduction, we use Clapp and Fuchs' power framework..$^{20,50,51}$ Where Clapp and Fuchs focus primarily on corporate power in their framework, this review will consider the power of all actors with an interest in RPM. The forms of power in this framework are described below.

Instrumental power is the direct influence of one actor in relation to the behaviour of another. ${ }^{50}$ This can include, for example, influencing policy-makers through lobbying, providing direct inputs into policy consultations, 'revolving doors' whereby personnel move between industry and government regulatory agencies, political donations, and financing academic activities and sponsoring favourable research. $^{39,50}$ The food politics literature often refers to the instrumental power of 'Big Food' in shaping food and nutrition policies through their corporate lobbying and political financing activities in particular. ${ }^{61,62}$

Discursive power is the power to influence the underlying norms, values, and belief-systems that guide thinking and behaviour, ${ }^{50,63}$ as well as the apparent 'frames' in which issues are interpreted and openly portrayed. ${ }^{64}$ It can manifest in normalising 'truths' about a particular issue, and alter perceptions, often unconsciously, about what interpretations and solutions are considered acceptable or desirable. ${ }^{39}$ More obviously examples of discursive power include advertising and promotion, corporate social responsibility initiatives, and communicating scientific evidence. ${ }^{65,66}$ Discursive power can also underpin collective action - those who can agree on a common characterisation of a given problem (eg, that RPM is harmful to human health and the environment) may be more likely to mobilise support, counter opposition and influence decision-makers relative to those who are divided. ${ }^{67}$ Discursive power is also ideological - for example, the emergence of neoliberal free-market thinking and economic policies since the 1980s, has fostered strong preferences for market-based approaches to governance (eg, publicprivate partnerships), deregulation and a minimal role for government intervention. ${ }^{68,69}$

Structural power is the power to control the "range of choices available to others." ${ }^{0}$ For example, governments often define policy agendas, may decide who participates and who is excluded from the policy-making process, and can adopt command-and-control regulation to shape the choices and behaviours of others. Corporations often adopt 
private standards, for example voluntary codes on responsible marketing or supply chain sustainability, with the intention of delaying or even completely replacing regulation by government. ${ }^{50,63}$ Globalisation has enhanced the structural power of transnational corporations, by making it easier to transfer capital investments across national borders, meaning governments must increasingly compete for those investments by creating business-friendly policy environments (eg, by relaxing regulatory standards, or providing tax concessions), over the protection of public health or the environment. ${ }^{61}$ Public-private or multi-stakeholder partnerships further enhance the structural power of corporations in setting public policy agendas and decision-making. ${ }^{61}$

\section{Literature Search and Study Selection}

A detailed explanation of the search process can be found in Supplementary file 2. This involved three steps. First, a scoping review was performed initially to both identify and group relevant search terms, as well as to identify an appropriate guiding framework. Consultation with a Deakin University Research Liaison Librarian was undertaken in order to ensure comprehensiveness of search terms, as well as reviewing effective search strings and suitable databases for searches. Second, four databases (Scopus, Web of Science, PubMed, and EBSCO Host) were searched for relevant studies. Search terms such as "meat," "beef," "livestock," "health," "sustainab*," and "polic*" were used. Additional branching searches were conducted to ensure comprehensiveness of included literature, as new knowledge and references were identified. Third, the websites of authoritative organizations with a mandate or interest in improving nutrition, public health and/ or environmental sustainability were also searched to identify relevant reports, policy briefs, or other documents. These included WHO, the Food and Agricultural Organization (FAO), Committee on World Food Security, IPCC, Food Climate Research Network, International Panel of Experts on Sustainable Food Systems, EAT, United Nations Standing Committee on Nutrition, International Fund for Agricultural Development, World Bank, and the World Economic Forum.

Analysis and Final Synthesis

All studies were uploaded to NVivo12, the qualitative analysis software. ${ }^{70}$ The results were then coded against the theoretical framework, and themes were identified and iteratively refined using constant comparative analysis. ${ }^{71}$ This allowed for nuance to emerge throughout the analytical process. The findings were then synthesised, organised in accordance with the framework in order to present the results of the analysis.

\section{Results}

The literature included in this review was sourced from a wide range of disciplines including public health, economics, agricultural science, food policy, and business studies. The majority of studies were from high-income countries such as the United States, the United Kingdom, Australia, and Sweden. Studies covered a diversity of policy issues and political challenges relating to meat reduction. Guided by the conceptual framework, the following sections summarise these issues and challenges.

First, we discuss how high levels of RPM production and consumption are sustained through interests, ideas and institutions that have historically constituted food systems, starting with an introduction to the relevant actors and their interests. Second, we then review the instrumental, discursive, and structural power of actors.

\section{Actors and Their Interests}

Actors identified in the literature with an interest in meat and meat reduction include governments, civil society groups, businesses and industry groups, researchers and consumers. The majority of the literature focused on the power of the meat industry in relation to meat reduction, however other key actors were also acknowledged including novel protein industries (such as plant-based imitation meat or cell-cultured meat), governments and international organisations, and civil society groups and citizens.

\section{Businesses and Industry Groups}

The literature identified the meat industry as the most powerful interest group promoting high levels of RPM consumption, and resisting reduction efforts. The term 'meat industry' refers to 'market' actors specifically - those that have private interests, are for-profit and comprise the modern industrial livestock sector, including production (including animal feed and pesticides), packing, preservation, retailers (such as supermarkets and fast food chains), representative peak organisations, as well as ancillary service providers such as the advertising industry. The most powerful RPM corporations identified in the literature were JBS (Brazil), Tyson Foods (USA), and WH Group/Smithfield (China). These three corporations dominate the global market. At the time of writing, they account for $63 \%$ of global market share for pork; with Tyson and JBS controlling 46\% of the market for beef. ${ }^{72}$ Animal feed and technology input suppliers such as Cargill (USA) and Bunge (USA) were also noted to be powerful corporate players, given their sizeable reach as some of the largest agricultural commodity traders in the world. ${ }^{40}$ Together, these can be collectively referred to as 'Big Meat.' In addition to these global, large-scale, industrial companies, the meat industry also consists of small- and medium-sized players in domestic markets, including farmers and local industry associations. The market structure varies by country in this regard, for example, the US meat market is highly concentrated with large global corporations ${ }^{73}$ whereas in countries like New Zealand, the market is characterised by a diversity of domestic producers. ${ }^{74}$

A small number of studies identified alternative protein industries as actors who stand to gain from RPM reduction. Alternative proteins encompass four primary categories traditional vegetarian proteins, novel plant-based proteins, edible insects, and 'cellular agriculture' (lab-grown meat). ${ }^{75,76}$ Some corporations participate in both the alternative protein and RPM markets. For example, many fast food retailers are diversifying into plant-based meats as a means to expand their marketing options and to be seen as market leaders 'shifting (with) the agenda.' As the call for reduced meat consumption 
has gained traction in the public sphere, replacing meat with these alternatives has become a more financially lucrative opportunity. This has also caught the attention of Big Meat and powerful animal feed corporations, leading many to acquire alternative protein start-ups and position themselves as market leaders in the area. For example, Cargill increased investments in 2019 into Puris, a pea protein production company, of up to $\$ 75$ million. ${ }^{77}$ Other animal feed companies are following suit. Bunge Ltd, one of the largest soy and grain traders globally, purchased a $1.6 \%$ stake in Beyond Meat in 2019, showing remarkable foresight as the market capitalisation of Beyond Meat was around $\$ 9.9$ billion at the time of writing - significantly greater than Bunge Ltd, despite being a firm with over 30000 employees and existing in the market for over 200 years. $^{78}$

\section{Governments and Inter-governmental Organisations}

In many countries, the RPM sector is economically important to governments given its contribution to gross domestic product, tax revenues, and exports and employment, especially in rural areas. In Australia, for example, the economy is reliant on the industry as one of the key exporters and a major source of employment, particularly in rural areas where over 191000 people are directly employed by the meat and livestock sector. ${ }^{79}$ Furthermore, a variety of government departments have a mandate that includes supporting the RPM sector alongside other roles and responsibilities, including agriculture, health, food standards and the environment, creating a challenge of policy coherence and often leading to conflicting objectives. ${ }^{80}$ For example, a department of agriculture in a given country may be responsible for policies supporting the RPM sector (such as farming subsidies) and for environmental protection (such as water usage).

Unlike commercial actors where profit is the predominant driving force behind decision-making, governments can have a widespread agenda with multiple interests at play, including the health of their citizens and environmental concerns. For example, China's government has included a recommendation to reduce RPM consumption to 40-75 g of meat per day in their dietary guidelines. ${ }^{81}$ These recommendations were distributed to citizens through a series of public information advertisements, with environmental conservation at the core of the message. It is estimated that almost one billion tonnes of carbon and methane emissions from the livestock industry could be reduced from China's emissions output should these guidelines be widely adopted. ${ }^{81}$

Some studies recognised the role of intergovernmental organisations as both facilitators and barriers to RPM reduction. Intergovernmental organisations such as WHO, FAO, IPCC, and the High Level Panel of Experts on Food Security and Nutrition (HLPE) play largely technical, normative and convening roles in global food systems governance. This includes, for example, producing policy reports and guidelines such as the highly-cited "Livestock's Long Shadow" by FAO, ${ }^{82}$ "Climate Change and Land" by IPCC $^{83}$ and "Sustainable agricultural development for food security and nutrition: what roles for livestock?" by HLPE. ${ }^{84}$ Technical work, for example the WHO-International
Agency for Research on Cancer (IARC) "Monographs on the evaluation of carcinogenic risks to humans: red meat and processed meat" ${ }^{\prime \prime}$ help to provide an evidence base for informing meat reduction.

The Codex Alimentarius Commission (Codex), the United Nations body administered under the joint FAO/WHO Food Standards Programme, has a dual mandate to protect public health and safety while facilitating international food standards harmonisation and trade. Codex standards are important because they inform food-standard setting by governments. Interestingly, Codex 'commodity-specific' committees relevant to meat including the Committee on Meat and the Committee on Processed Meat and Poultry Products were abolished in 1973 and 1990 respectively, and the Committee on Meat Hygiene adjourned indefinitely in 2005. ${ }^{85}$ However, meat products fall under General Subject Committees, for example those mandated to set standards on additives, labelling and hygiene. Codex standards are also important as reference standards in trade agreements, including in the World Trade Organization's (WTO's) Technical Barriers to Trade and Sanitary and Phytosanitary Measures Agreements.

Trade policy and/or conflicts with WTO rules were a barrier cited in the literature for some member states attempting to regulate the import and export of RPM. ${ }^{23,32,86-98}$ For example, in order for Samoa to join the WTO, the government had to reverse an already-implemented restriction on fatty meat imports that had been employed as an anti-obesity measure. ${ }^{23}$ In another example, the European Community (EC) banned the import of meat products containing artificial hormones, leading to a sizeable dispute between the EC and the United States in the WTO Dispute Settlement Body as a result. ${ }^{99}$ The WTO ultimately ruled against the EC. In contrast, the development of national standards in Ghana led to the restriction of imports of some high-fat meats and reduced the availability of these products in the Ghanaian food supply, whilst still adhering to global trade law. ${ }^{100}$

\section{Civil Society Groups and Citizens}

The literature cites a number of civil society actors with an interest in meat reduction. Civil society actors can be defined as "public interest non-governmental organisations, social movements, research organisations and academics, communities and consumers." 39 For example, in the United States, the Reducetarian Foundation, works to form networks between environmental, health, and social justice organisations and individuals to promote RPM reduction through public education and engagement. ${ }^{101}$ The collective power of these groups can also pressure governments to take action. This is evident in Denmark where a "meat tax" was proposed to Parliament following the release of a publication by the Danish Council of Ethics, an influential think-tank. ${ }^{102}$ Whilst the tax did not eventuate in law, it demonstrates the important norm-promotion role that civil society groups can play. Furthermore, public education surrounding the issue of RPM and its associated harms has markedly increased in part due to signature reports from research groups such as International Panel of Experts on Sustainable Food Systems, ${ }^{40}$ 
EAT-Foundation, ${ }^{32}$ World Cancer Research Fund, ${ }^{9}$ and the World Wildlife Fund. ${ }^{103}$

Some civil society groups have been reluctant to advocate for significant reductions in RPM consumption. One study noted that strategic considerations and feasibility of the message (ie, not wanting to disconnect from the mainstream views about meat) was a primary reason for this. ${ }^{104}$ Furthermore, depending on the motivation of the varying groups, efforts to influence policy can be stymied as a result of inconsistent messages about the amount of meat reduction needed versus advocacy for the complete removal of RPM consumption. For example, an environmentally or public-health motivated advocate may be content with simply reducing RPM consumption, ${ }^{104,105}$ however an animal advocate would argue that only complete removal of RPM can meet their goals. ${ }^{106}$ Within this, the extent of reduction can vary depending on the outcome of human health or carbon emissions.

A small number of studies also noted the role of vegetarian movements endorsed by civil society groups. For example, in the United States, 'Meatless Monday' is a public health initiative revived by Johns Hopkins School of Public Health in 2003 (having originated in World War I) across the country. ${ }^{107}$ The campaign aimed to reduce people's meat consumption incidentally by encouraging schools, hospitals, dining services and individuals to abstain from meat one day a week. ${ }^{108}$ Local organisations such as Compassion Over Killing, a not-for-profit in Los Angeles, were strong advocates of the movement. ${ }^{109}$ This campaign, in addition to other promotions of plant-based meals such as recipe cards, ${ }^{110}$ represents a strong opportunity to normalise diets that are less meat-heavy.

\section{Ideas}

Literature about ideas that formed barriers or enablers of RPM reduction policy fell under three broad themes - carnism, the production and communication of knowledge and evidence, and contestation of optimal policy solutions.

\section{The Ideology of Carnism}

Deeply entrenched in most cultures is the idea that 'a meal is not a meal without meat.' In some studies, this ideology is referred to as 'carnism, first coined by sociologist Melanie Joy. ${ }^{111}$ Carnism contends that the choice to eat meat is an ideology that positions consumption as "natural, normal, and necessary"111 on the basis that humans evolved to eat meat, and survival and strength depend on it. ${ }^{112,113}$ Preferences for red meat in particular have colonial origins, where Europeans were depicted as strong and superior in contrast to the 'weak' and 'feminine' First Peoples of their colonised nations, whom consumed largely plant-based diets. ${ }^{114}$ Norms and narratives around eating meat have been cited as a significant reason behind the policy inertia in this area. ${ }^{97,115-128}$ Policies aimed at reducing RPM consumption - in high-income countries in particular - would require a "profound societal transition" as the value of meat in these contexts is high, and often one of the more popular food products in many countries. ${ }^{116}$ Carnism and consumer demand reinforce each other in a causative loop, as demand levels have pushed meat production to intensive levels, allowing meat prices to fall, thereby helping to sustain high levels of consumption.

Meat is also deeply tied to social identity, in particular masculinity, as eating red meat has become synonymous with increased strength and "being a 'real' man" 129 The association of meat with masculinity has contributed to higher levels of meat consumption among men compared with women in the United Kingdom, the United States, and other high-income populations. ${ }^{130,131}$ Carnism may also underlie attempts to reserve particular terminology only for RPM. In the US state of Mississippi, legislation passed stipulating that plant-based food products were prohibited from being labelled as "meat" or "meat food product" (for example, 'vegan bacon' or 'veggie burger'), following intense lobbying from meat industry lobby groups, ${ }^{132,133}$ concerned that the ideological threat of these imitation products may impact 'traditional' meat profits. In July 2019, the Plant Based Food Association and member company 'Upton's Naturals' filed a lawsuit against the legislation, ${ }^{133}$ however this was subsequently dropped. ${ }^{134}$ This is an example of 'discursive power' as corporations seek to retain RPM as "real" and "natural" in comparison to plantbased counterparts.

One study acknowledged that cognitive dissonance leads meat consumers to avoid or resist evidence of the negative consequences of meat eating. ${ }^{135}$ Social and cultural norms in this regard have been described as powerful and pervasive, ${ }^{135}$ including the dissociation of meat from its animal origin in the language used to describe it (eg, using "beef" instead of cow, "pork" instead of pig). ${ }^{136}$ A recently published qualitative study from Australia describes persistent underestimation of the environmental impacts of red meat by consumers. ${ }^{137}$ Considerably less public scrutiny has been placed on RPM industries than the fossil fuel industry, despite the relatively similar GHG emissions output. The Institute for Agriculture and Trade Policy shows that combined, the top five meat and dairy companies globally (JBS, Tyson Foods Inc, Cargill, Dairy Farmers of America and Fonterra Group) emit more GHGs than large-scale oil corporations such as Exxon Mobil or Shell. ${ }^{138}$ Consumers can also be apathetic to the environmental risks of RPM. In a survey of supermarket shoppers conducted by Meat and Livestock Australia in 2019, the main consumer priorities were price, quality and freshness, with no mention of animal welfare or environmental concerns. ${ }^{139}$ This policy omission links with the ideological premise that meat is a normal and necessary part of daily life, and responsibility for GHG emission reduction should lie with other 'less natural' industries, such as plastic manufacturing or fossil fuels.

\section{Neoliberalism and Productivism}

Another key theme was how high levels of meat production and consumption are enabled by deeper belief systems that preference free markets and economic growth over health and environmental objectives. Many countries have embraced neoliberal ideologies that promote 'free-market' economic policies, deregulation and a minimal role for government intervention. This has allowed for the substantial growth in size of transnational food corporations, with power shifting away from both state and civil actors and governance being 
positioned in a more market-orientated form. ${ }^{39}$ This growth has only been amplified with the financialisation of much of the global food economy, involving the growth in marketised securities, monetary exchange freedoms, and financial sector deregulation..$^{40,141}$ Neoliberalism reinforces, and is reinforced by a 'productivist' policy paradigm, which has formed the basis for agricultural law and policy, especially in high-income countries, since the 1960s. This manifests in the promotion of agricultural efficiency, high crop-yields, export-orientated growth, and technology and resourceintensive inputs. ${ }^{142}$ Policy outcomes linked with productivism include widespread use of intensive factory farming and the overproduction of meat, particularly in high-income countries. ${ }^{143,144}$ Lang et al note that while this has allowed for lower priced meat for consumers, it encompasses hidden, or unaccounted for, costs, such as the cost of climate change or healthcare costs associated with antibiotic resistance. ${ }^{123,142}$

\section{Institutions}

Institutions are the formal and informal 'rules of the game' that actors follow as they endeavour to achieve their goals and interests. ${ }^{59}$ They can include formal structures like historical policy priorities or private-public partnerships, but also can include informal arrangements such as norms that guide policy-making. Major themes that emerged from the literature include financial relationships between governments and RPM industries, trade agreements and investment law, and policy incoherence.

Institutionalisation of Government-Meat Industry Co-dependence Given the sizeable economic impact of RPM and its cultural importance within many societies, the stability of the meat industry is also a key interest for many governments. In Australia, the red meat industry generates returns of above $\$ 22$ billion annually. ${ }^{79}$ This is in part thanks to the Australian government's commitment to provide the agricultural sector with "research and development funding, levy monies and facilitation of the management of issues of national importance." 145 Government subsidies in a number of countries have historically been employed as an important function of 'productivism.'142 Over time these subsidies have led to a surplus of foods and a multitude of human and planetary health problems. The Food and Land Use Coalition estimated that of the over US\$700 billion given annually across subsidy programs worldwide, around $\$ 530$ billion is paid to agricultural farmers. ${ }^{146}$ In the United States, $63 \%$ of subsidies are directed towards meat and dairy. ${ }^{147}$

As a result, many studies identified a co-dependency between governments and the RPM industry, being perpetually reinforced. One study found that any efforts by policy-makers to reduce RPM consumption would likely result in the mobilisation of "powerful interest groups."135 In the United States, for example, animal agribusinesses are worth around $\$ 125$ billion, and are highly concentrated. This market concentration is supported by government subsidies which generally favour dominant firms over smaller competitors. $^{72}$ For example, as the largest RPM producer in the United States and the second largest in the world, Tyson
Foods Inc. receives discounted corn and soybeans for animal feed and direct payments to farmers from the US Department of Agriculture (enabling savings of $\$ 288$ million USD per year). ${ }^{72}$ Attempts by governments to regulate or enforce technological reform on the industry have therefore been evaded due to the weight of "well-connected, large-scale commercial productions." ${ }^{2}$ Furthermore, many politicians in countries like Australia see supporting the red meat industry as integral to retaining electoral seats in swing states, ${ }^{80}$ and thus are reticent to challenge the status-quo.

\section{Trade Agreements and International Investment Law}

The growing number of regional and bilateral trade agreements, in addition to the wider structures of international trade and investment law (including investor-state dispute settlement mechanisms and arbitration bodies), have contributed to significant challenges for domestic policy-making in relation to meat reduction. To date, food safety and livestock disease are the primary considerations given for restricting imports of meat products, rather than health and environmental concerns. ${ }^{23}$ Countries compromising on existing public health policies in order to join the WTO and other regional and bilateral trade and investment agreements (as exemplified earlier with Samoa). These policy conflicts can continue after countries accede to the WTO, as member states can engage in trade policy review processes and arbitration to challenge the regulations adopted by other governments. The threat of trade arbitration can also result in 'regulatory chill', whereby policy-makers are deterred from taking regulatory action in the first place. ${ }^{148}$ Furthermore, the proliferation of preferential trade agreements that go beyond the WTO in terms of depth and scope of provisions are also key considerations. For example, the lowering of trade barriers between the US and Mexico under the North American Free Trade Agreement, saw a significant increase in meat products being imported into Mexico between 1994 and 2008. ${ }^{149,150}$

\section{Policy Incoherence}

The literature observed a diversity of approaches to meat reduction, highlighting a difference between siloed or targeted approaches compared with systemic ones involving coherent policies and actions across multiple sectors. Studies tended to demonstrate a preference for isolated or one-off regulatory proposals, usually aimed only at either production or consumption. Meat taxes (either point-of-sale or production-based), ${ }^{86,87}$ consumer labels, ${ }^{151,152}$ or innovations in agricultural technologies ${ }^{118,153}$ were the most commonly promoted policy proposals but rarely synergistically, and for the most part burdening the consumer. This highlights that existing governance structures in most countries are strongly institutionalised, with a tendency towards siloed approaches, subsequently resisting the adoption of system-wide packages of policy actions. However, as mentioned above, expert bodies such as The Commission ${ }^{32}$ have stipulated that transforming the food system - including reducing RPM production and consumption - will require a range of policy actions that work synergistically across multiple food systems drivers. Despite this, a substantial number of studies proposed 'silver- 
bullet style' or individual policy actions for RPM reduction, not packages of actions that addressed multiple drivers. Implementing siloed policy actions as a means of addressing the ecological harms associated with RPM production neglects to address the interconnected challenges of the wider system, ${ }^{154,155}$ however this has historically been the process for policy development due to the pre-existing nature of policymaking.

\section{Instrumental Power}

The literature generally identified the meat industry as the actors with the most instrumental power. A broad range of literature examines the power of large transnational companies with a disproportionate level of power in the food system. Examining the use of power by these companies in the food system, ie, "Big Meat," is central to understanding why policies do and do not get made. The term "Big Food" has been applied by researchers and civil society to describe large-scale transnational food and beverage corporations such as Nestle and Coca Cola, actors that are incredibly powerful in the food system and actively utilise their power to maintain favourable market environments, in many cases prioritised over health and/or environmental impacts. ${ }^{61,156,157}$ Many of the strategies and forms of power used by these industries are being replicated by the meat industry in response to any suggestion of policies designed to reduce RPM. ${ }^{80}$

Given that in many high-income countries the livestock sector constitutes around $40 \%$ of total agricultural output, ${ }^{158}$ and processing and retailing also constitute substantial economic sectors in domestic markets around the world, these actors can apply varying forms of instrumental power when it comes to influencing regulation or policy. ${ }^{51,116}$ For example, many studies reveal lobbying as a key practice in circumventing policy targeted at meat reduction. In 2018, Tyson Foods spent US\$1.1 million on US federal lobbying alone, ${ }^{159}$ dominating the lobbying spending efforts of other meat processing corporations and resulting in it being one of the most powerful companies domestically. In both the United States and Australia, meat industries applied considerable pressure throughout the development of their respective national dietary guidelines, later was acknowledged by various organisations to be a strong influence on the final recommendations that omitted any mention of reducing meat consumption ${ }^{23}$ or "environmental sustainability" considerations. ${ }^{160}$ Peak representative organisations also engage on behalf of these companies, such as the National Pork Producers Council in the United States, which invested over US\$2.4 million lobbying against proposed legislation aimed at addressing water quality, antibiotic use and trade in the meat sector. ${ }^{161}$ Even in the context of the global SARS-Cov-2 2019 pandemic, Tyson Foods lobbied the Trump Administration to reopen processing factories despite slaughterhouses being considered "coronavirus hot spots" and a clear risk to workers. ${ }^{162}$ Furthermore, related input corporations such as Cargill, and those involved with distribution (such as food retailers and restaurants) have also engaged in extensive lobbying activities. ${ }^{163}$ In Brazil this has been done in order to privatise land, that more often than not has belonged to indigenous or intergenerational farmers, in order to sell to transnational corporations or foreign countries, is also commonplace and an example of instrumental power. ${ }^{51,164}$

\section{Discursive Power}

\section{Framing the RPM Reduction Problem and Solutions}

Discursive power is evident in the frames used by actors to interpret and portray the RPM reduction problem and what solutions are considered optimal or desirable. There is much contention over whether or not RPM harms population and/ or planetary health. Various studies have demonstrated that despite the mounting evidence to the contrary, media coverage and consumer consciousness of the problems of meat tend to be low. ${ }^{165,166}$ Furthermore, meat reduction has frequently been framed as extremist, associated with the 'vegan agenda, by many individuals and interest groups, including the meat industry. ${ }^{167,168}$

As described earlier, the Commission proposes a package of food systems policy interventions to achieve its ambitious dietary targets. These include international and governmental support to regulate trade, removing farming and agricultural subsidies, attenuating livestock production, strengthening governance around environmental resources, and targeting consumer behaviour change. ${ }^{32}$

However, some proposals are promoted more than others, connecting to wider societal values of technological innovation and ideas of personal responsibility. For example, agricultural technologies that use less water and improve manure and herd management, nitrogen efficiency, and feeding practices, as a means of reducing emissions associated with RPM production are heavily favoured by industry groups. ${ }^{118,169}$ Ruminant meat production is in a unique position in this regard, as not only are there opportunities to reduce carbon emissions from the farming process, but also to facilitate carbon sequestration ie, pulling and absorbing carbon from the atmosphere. This is because both grazing and excretions from ruminant animals can stimulate plant growth and carbon fixation, making nitrogen in particular more available to the next generation of plants..$^{23,121}$ Solutions like these shift blame away over their production practices, whilst simultaneously positioning themselves as 'part of the solution' - a commonly utilised mechanism of influence by other industries such as "Big Soda." ${ }^{61,170}$ However, there is little consensus around whether these 'negative emissions technologies' are sufficient to meet emission reduction goals needed for safe planetary boundaries, ${ }^{31,171}$ and especially not as an isolated measure. ${ }^{172}$

A number of studies supported by industry or industry interest groups (such as Meat and Livestock Australia) propose consumer labelling as a policy action. ${ }^{33,34}$ Sonoda et al found that three key consumer values influenced the effectiveness of labelling for meat; $(i)$ openness to change, (ii) self-enhancement, and (iii) security. ${ }^{173}$ However, these values - and thus the effectiveness of consumer labels - have been noted to be superseded by price and taste preference by Van Loo et al. ${ }^{174}$ It is unsurprising that industry would advocate for labelling schemes given the onus of this style of policy action lays in the hands of consumers and directing consumer 
choice, rather than governing land use or applying limits to RPM production practices, which would require major structural and financial reform for the RPM sector. ${ }^{175,176}$ Policy solutions such as labelling also reinforce ideas of 'personal responsibility' and put the onus onto the consumer to make the changes required to mitigate the effects on sustainability and health. ${ }^{177}$

Many academics have acknowledged the limitations of such siloed approaches to policy-making and have reinforced the need for systemic and multi-issue responses. Parker and Haines argue that regulation needs to adapt to make ecology a primary concern (known as 'ecological regulation'), stating that human governance systems need to operate within ecological limits for humans, whilst ensuring social and economic pressures are included as part of a wider synergistic approach. ${ }^{154}$ This type of regulation might include measures such as penalising atmospheric emissions by highcontributing industries, such as the fossil fuel or agricultural sectors. ${ }^{154,155}$ Others advocating for integrated responses espouse the importance of incorporating sustainability across multiple policy areas, including that of dietary guidelines. ${ }^{36,178}$ Furthermore, the unequal balance of power among various actors in the food system was noted in the literature, suggesting that stronger state-led and participatory models of governance will be required to achieve RPM reduction. ${ }^{36,39}$

\section{Producing and Influencing Knowledge and Evidence}

The use of knowledge and evidence, as well as the power to produce, shape, disseminate and contest ideas, and narratives within these, is an example of discursive power. Establishing a sound body of evidence to support meat reduction is an important prerequisite for policy development and gaining public support. This power can be utilised by public health academics through, for example, the publication of evidence that elucidates the risk of colorectal cancer from excessive RPM consumption, which contributes to the idea that there are health harms associated with RPM, and therefore creates an idea that consumption should be reduced (red meat) or avoided (processed meat). Several major systematic reviews support this, including the WHO IARC review. ${ }^{179}$

RPM industries and their representatives have sponsored research or funded academics as a means of discrediting, or at the very least, disputing some of these concerns. For example, a 2011 study funded by the US National Cattlemen's Beef Association ${ }^{180}$ found no correlation between RPM consumption and colorectal cancer. Similarly livestock industry associations such as Meat and Livestock Australia have provided ongoing financial support to the Australian Commonwealth Scientific and Industrial Research Organisation, leading to allegations of biased outcomes. ${ }^{181}$ RPM industry support has also been provided for research published in international publications, such as the widely publicised review of RPM on health outcomes in October 2019 in Annals of Internal Medicine. The study authors had received funding from Texas AgriLife Research, as well as the International Life Science Institute, an industry front group. ${ }^{182}$ The study concluded that the quality of evidence for RPM-related health harms was low. ${ }^{183}$ It was accompanied by a clinical guideline recommendation for adults to "continue current processed and unprocessed red meat consumption" due to the low-certainty evidence. ${ }^{184}$ The disputing of evidence about the impacts of RPM make policy development processes more difficult as they are used by industry to refute regulatory attempts. ${ }^{185}$

\section{Structural Power}

\section{Concentration Within Global and Domestic Meat Markets}

A recurring theme in the literature was the structural power connected to highly concentrated global and domestic meat markets. Highly concentrated markets give companies considerable power to reduce their own costs by imposing price restraints on suppliers and at the same time setting private standards for product processes and quality. ${ }^{40}$ This forces meat suppliers to become more efficient, which drives market concentration across the meat supply chain. It also enables companies to provide cheaper meat products to consumers, further perpetuating meat consumption. ${ }^{35,186}$ Market power also enables companies to leverage power over consumers, by constraining the choices available in markets. ${ }^{50,51}$ Although many meat markets are primarily domestic, there are several highly-capitalised multinational corporations that operate across dozens of countries, engaging in trade and competing with medium- and small-sized local businesses. Globally, four firms (Tyson Food - 24\%, JBS - 22\%, Cargill - 19\% and National Beef - 10\%) control $75 \%$ of all beef-processing and four firms control 70\% of pork processing (WH Smithfield $26 \%$, JBS - 19\%, Tyson Food - 17\%, Orwell - 8\%). ${ }^{40}$ In recent decades these corporations have accrued considerable market power by concentrating vertically and horizontally across and within supply chains through mergers, acquisitions and other anti-competitive market activities. The structural power of these companies can lead to the leveraging of capital mobility in order to achieve policy concessions. ${ }^{39}$

Nowhere has a government been more overt in their protection of RPM than in Brazil. Since 2018, the Bolsonaro administration has actively removed barriers to deforestation of the Amazon in favour of livestock land clearance. ${ }^{187}$ This has included budget cuts of $95 \%$ to the National Policy on Climate Change, introducing bills to reduce environmental requirements, and attempting to decrease the authority of the National Indian Foundation, which protects indigenous land rights. ${ }^{164}$ This is a clear example of structural power where concessions are made to domestic and transnational companies to attract investment as well as the jobs and revenue they provide, even if much of the benefit ends up offshore.

\section{Government and Public Procurement}

The literature noted some capacities for governments to play in support of meat reduction. Whilst partnerships between government and civil society are not widely discoursed in this area, there are a few noted opportunities for cooperative-style regulation for meat reduction. Procurement policies (such as meals in schools, hospitals, and catering in government departments) present openings for institutionalised reduction of RPM. ${ }^{160,163,188}$ Governments and civil society can use procurement policies to challenge the power of industry 
by being role models as well as reducing demand for RPM production and consumption. ${ }^{151}$ This strategy has been used in many European countries to increase sales of organic food and increase the acceptability and preferences of organic food to the consumers through hospital cafeterias and schools. ${ }^{151}$ However, health advice for procurement policies are often informed by national dietary guidelines, which can be heavily influenced by industry. ${ }^{163}$

\section{Discussion}

Reducing the production and consumption of RPM is a key area of reform needed to meet global environmental and health targets, such as limiting anthropogenic global warming to no more than $2^{\circ} \mathrm{C}$ and attenuating global levels of chronic disease. However, the means by which this is to be achieved is contested, and political factors that may enable or constrain the implementation of meat reduction policies is underinvestigated. The aim of this literature review was to identify and understand key political economy challenges of reducing the production and consumption of RPM, in order to inform societal actions towards healthy and sustainable food systems.

How these political factors may enable or constrain the implementation of policy actions were summarised against a conceptual framework incorporating interests, ideas, and institutions as categories, ${ }^{48,49}$ and a power framework including instrumental, discursive, and structural forms of power. ${ }^{20,50,51}$ This review identified the varying political factors that stand to either enable or constrain the systematic efforts to reduce the harms associated with RPM production, marketing and consumption.

The empirical findings reviewed demonstrate the intricacy of the RPM problem and why policy aimed at addressing this problem has remained largely stagnant. It highlights the need to address actors, ideas, and institutions; and the ways in which power is currently supporting the production and consumption of RPM in the food system. A consistent pattern was observed across the potential barriers and/ or enablers for RPM reduction. Firstly, most barriers to RPM reduction identified in the literature involve industry actors and commercial interests, including trade, market concentration, and for some countries, government-industry dependence. This is not surprising given that RPM, like other foods, are generally regarded as commodities to be traded for profit. Broader ideas and ideologies, including carnism and neoliberalism, also protect industry interests. A paradigm shift in mainstream policy-making would therefore be a vital component in addressing the barriers to RPM reduction.

This review did identify enabling actors who may assist in furthering policy efforts around RPM reduction, including governments, inter-governmental organisations such as WHO, FAO, and the IPCC, and certain non-governmental organisations. Currently these actors wield less instrumental and structural power than that of industry and industry interest groups, and subsequently are prevented from actioning effective change within the food system. For example, government and meat industry interests are inextricably linked in relation to jobs and economic benefits. Addressing this power asymmetry should be a core component of the food system transformation, and could include realigning incentives in the food system to reduce market concentration, restructuring governance structures that provide more widespread corporate oversight, and building more equitable supply chains under a new economic paradigm (and shifting away from productivism). ${ }^{40}$ Further opportunities exist for civil society groups to work in cooperation with government to gain power over industry and promote meat reduction, however this is likely to also require a shift in ideology and paradigms - most notably, the ideologies of carnism and productivism. The discursive power of consumer concern for their own health, and for some, the environment, may be a possible resource for change.

In contrast to Parker and colleagues' call for holistic, ecologically-focused regulation, ${ }^{154}$ policy proposals to attenuate RPM production and consumption have been suggested primarily in isolation and not reflected within a food systems lens (for example, several studies modelled effects of a 'meat tax' as a sole policy proposal). Furthermore, the political viability of implementing these suggested policy actions has largely not been considered in the studies. This is understandable, as political economy of health outcomes and issues within the food system is an emerging area of research. ${ }^{189}$ While public health nutritionists have focused on the political economy of ultra-processed foods and sugar sweetened beverages, little attention has been paid to the political economy of meat. Although a range of other disciplines do actively consider RPM production and consumption (for example geographers and business researchers), a political economy lens may be outside the scope of their usual research approach. This opens up prospects for further research that is focused around political feasibility of meat production proposals and opportunities for systemic change.

Whilst the complexity and nature of the RPM problem may make it seem that policy efforts aimed at reduction are a fool's errand, previous instances of 'wicked problems' have been successfully overcome. Tobacco was seen as a largely insurmountable public health issue in many countries for decades. ${ }^{190}$ However comprehensive and multi-sector strategies have constrained the transnational power of tobacco companies like Phillip Morris (instrumental power), emphasised the health harms associated with smoking (discursive power), and underscored the importance of policy networks (structural power). ${ }^{80}$ As a result tobacco control has, for the most part, been counted as a significant public health success. The prevailing feature of success in that instance was not a sole policy action, but rather, many, at multiple levels and areas of governance. ${ }^{80}$

\section{Strengths and Limitations}

This is the first study to conduct a critical political economy review of evidence around RPM reduction, incorporating the 3 I's framework with Clapp and Fuchs' power framework. It also adopted a multi-disciplinary approach, through a search across three databases in order to capture the widest array of literature possible.

This review has several limitations. Firstly, our search strategy may have omitted relevant studies due to the size 
of scope. This omission could have affected the number of studies included in the analysis due to a number of literatures being inadvertently excluded. Furthermore, as is consistent with narrative review methods, the results of this study are inherently subject to bias and cultural interpretations of the authors. Determining and integrating complex interactions between themes and ideas is difficult, particularly with large sets of studies.

\section{Conclusion}

Achieving healthy and sustainable food systems in the wake of urgent calls to address their contributions to poor human health and environmental degradation should be multifaceted and address multiple levels of the food system. However, understanding the role of power in working towards this transformation has been critically under investigated. At the root of any human system is power, and the food system is no exception. In the context of RPM, high consumption levels are an outcome of widely prevailing asymmetries of power that have gone largely unchallenged. Therefore, research around policy efforts to reduce RPM production and consumption cannot omit the role of power.

This area of research is dynamic and has a rapidly moving and changing set of agendas, stakeholders, science, and politics. New issues are likely to arise and politics will shift over the coming years and decades. However, the negative impacts of continued RPM production and consumption on the environment, loss of natural resources, and the rising temperatures of our planet, will ultimately affect everyone, suggesting that sooner or later enough actors will realise it is in their interests to act together to reduce RPM production and consumption.

Ethical issues

Not applicable.

Competing interests

Authors declare that they have no competing interests.

Authors' contributions

KS and PB conceived the original topic for investigation and its aims. KS and PB designed the study, with contributions from $\mathrm{ML}$ and $\mathrm{CP}$. KS was responsible for the literature search, analysis, and drafting of the manuscript. KS, PB, CP, and $\mathrm{ML}$ provided a critical review of the manuscript. All authors contributed to and agreed on the final version.

\section{Authors' affiliations}

'School of Exercise and Nutrition Sciences, Deakin University, Geelong, VIC, Australia. ${ }^{2}$ Institute for Physical Activity and Nutrition, Deakin University, Geelong, VIC, Australia. ${ }^{3}$ Melbourne Law School, The University of Melbourne, Melbourne, VIC, Australia.

\section{Funding}

Katherine Sievert was supported by a National Health and Medical Research Council (NHMRC) Postgraduate Award scholarship.

\section{Supplementary files}

Supplementary file 1 contains Table S1. ${ }^{23,32,87-98,105,115-118,120-125,127,151-153,163,173,188,190-}$ 240

Supplementary file 2 contains the detailed explanation of the search process. ${ }^{41-43,70,241,242}$

\section{References}

1. Global burden of 87 risk factors in 204 countries and territories, 1990-
2019: a systematic analysis for the Global Burden of Disease Study 2019. Lancet. 2020;396(10258):1223-1249. doi:10.1016/s01406736(20)30752-2

2. Australian Bureau of Statistics (ABS). Australian Health Survey: First Results, 2011-12. ABS; 2013.

3. Australian Institute of Health and Welfare (AlHW). Risk Factors to Health, Nutrition. Australia: AlHW; 2017.

4. Global, regional, and national age-sex specific mortality for 264 causes of death, 1980-2016: a systematic analysis for the Global Burden of Disease Study 2016. Lancet. 2017;390(10100):1151-1210. doi:10.1016/s0140-6736(17)32152-9

5. IARC Working Group on the Evaluation of Carcinogenic Risk to Humans. IARC Monographs on the Evaluation of Carcinogenic Risks to Humans. Lyon, France: International Agency for Research on Cancer; 2018.

6. Wyness $L$. The role of red meat in the diet: nutrition and health benefits. Proc Nutr Soc. 2016;75(3):227-232. doi:10.1017/s0029665115004267

7. De Smet S, Vossen E. Meat: the balance between nutrition and health. A review. Meat Sci. 2016;120:145-156. doi:10.1016/j. meatsci.2016.04.008

8. IARC Monographs. Red Meat and Processed Meat. Vol 114. Lyon, France: WHO International Agency for Research on Cancer; 2018.

9. World Cancer Research Fund. Meat, fish and dairy products and the risk of cancer. Diet, Nutrition, Physical Activity and Cancer: A Global Perspective. https://www.wcrf.org/sites/default/files/Meat-Fish-andDairy-products.pdf. Published 2018.

10. Cross AJ, Sinha R. Meat-related mutagens/carcinogens in the etiology of colorectal cancer. Environ Mol Mutagen. 2004;44(1):44-55. doi: $10.1002 / \mathrm{em} .20030$

11. Jägerstad M, Skog K. Genotoxicity of heat-processed foods. Mutat Res. 2005;574(1-2):156-172. doi:10.1016/j.mrfmmm.2005.01.030

12. Manz DH, Blanchette NL, Paul BT, Torti FM, Torti SV. Iron and cancer: recent insights. Ann N Y Acad Sci. 2016;1368(1):149-161. doi:10.1111/ nyas. 13008

13. Garnett T, Appleby MC, Balmford A, et al. What is a Sustainable Healthy Diet? A Discussion Paper. Oxford, United Kingdom: Food Climate Research Network (FCRN); 2014.

14. High Level Panel of Experts on Food Security and Nutrition (HLPE). Nutrition and Food Systems. A Report by the High Level Panel of Experts on Food Security and Nutrition of the Committee on World Food Security. Rome, Italy: HLPE; 2017.

15. Food and Agriculture Organization. Tackling Climate Change Through Livestock: A Global Assessment of Emissions and Mitigation Opportunities. Rome: Food and Agriculture Organization of the United Nations; 2013.

16. Reisinger A, Clark H. How much do direct livestock emissions actually contribute to global warming? Glob Chang Biol. 2018;24(4):1749-1761. doi:10.1111/gcb. 13975

17. Alkon AH. Food justice and the challenge to neoliberalism. Gastronomica. 2014;14(2):27-40. doi:10.1525/gfc.2014.14.2.27

18. Koch RM, Swiger LA, Chambers D, Gregory KE. Efficiency of feed use in beef cattle. J Anim Sci. 1963;22(2):486-494. doi:10.2527/ jas1963.222486x

19. Mekonnen MM, Hoekstra AY. The Green, Blue and Grey Water Footprint of Animals and Animal Products. Delft, the Netherlands: UNESCO-IHE Institute for Water Education; 2010.

20. Fuchs $D$, Kalfagianni $A$. The causes and consequences of private food governance. Bus Polit. 2010;12(3):1-34. doi:10.2202/1469-3569.1319

21. Food and Agriculture Organization (FAO). Cattle Ranching and Deforestation: Livestock Policy Brief. Rome, Italy; FAO; 2006.

22. Lundström M. The political economy of meat. J Agric Environ Ethics. 2019;32(1):95-104. doi:10.1007/s10806-019-09760-9

23. Godfray HCJ, Aveyard P, Garnett T, et al. Meat consumption, health, and the environment. Science. 2018;361(6399):eaam5324. doi:10.1126/science.aam5324

24. Henchion M, McCarthy M, Resconi VC, Troy D. Meat consumption trends and quality matters. Meat Sci. 2014;98(3):561-568. doi:10.1016/j. meatsci.2014.06.007

25. World Health Organization (WHO). 3.4 Availability and Changes in Consumption of Animal Products. WHO; 2000. https://www.who.int/ nutrition/topics/3_foodconsumption/en/index4.html.

26. Popkin BM, Adair LS, Ng SW. Global nutrition transition and the 
pandemic of obesity in developing countries. Nutr Rev. 2012;70(1):321. doi:10.1111/j.1753-4887.2011.00456.x

27. Peters GM, Rowley HV, Wiedemann S, Tucker R, Short MD, Schulz M. Red meat production in australia: life cycle assessment and comparison with overseas studies. Environ Sci Technol. 2010;44(4):1327-1332. doi:10.1021/es901131e

28. Ranganathan J, Vennard D, Waite R, et al. Shifting Diets for a Sustainable Food Future: Creating a Sustainable Food Future. World Resources Institute; 2016. http://www.wri.org/sites/default/files/ Shifting_Diets_for_a_Sustainable_Food_Future_0.pdf.

29. Patz JA, Frumkin H, Holloway T, Vimont DJ, Haines A. Climate change: challenges and opportunities for global health. JAMA. 2014;312(15):1565-1580. doi:10.1001/jama.2014.13186

30. Silbergeld EK, Graham J, Price LB. Industrial food animal production, antimicrobial resistance, and human health. Annu Rev Public Health. 2008;29:151-169. doi:10.1146/annurev.publhealth.29.020907.090904

31. Intergovernmental Panel on Climate Change (IPCC). Special Report on Global Warming of $1.5^{\circ} \mathrm{C}$ (SR15). IPCC; 2018.

32. Willett W, Rockström J, Loken B, et al. Food in the Anthropocene: the EAT-Lancet Commission on healthy diets from sustainable food systems. Lancet. 2019;393(10170):447-492. doi:10.1016/s01406736(18)31788-4

33. Parker C, Carey R, De Costa J, Scrinis G. Can the hidden hand of the market be an effective and legitimate regulator? the case of animal welfare under a labeling for consumer choice policy approach. Regul Gov. 2017;11(4):368-387. doi:10.1111/rego.12147

34. Parker C, Carey R, Haines F, Johnson H. Can Labelling Create Transformative Food System Change for Human and Planetary Health? A Case Study of Meat. Int J Health Policy Manag. 2021; Special issue.

35. Mason P, Lang T. Sustainable Diets: How Ecological Nutrition Can Transform Consumption and the Food System. London, United Kingdom: Routledge; 2017.

36. Garnett T. Food sustainability: problems, perspectives and solutions. Proc Nutr Soc. 2013;72(1):29-39. doi:10.1017/s0029665112002947

37. Baggini J. A Tax on Red Meat? That Won't Save the Planet - Or do Much to Improve Our Health. The Guardian. May 29, 2019. https:// www.theguardian.com/commentisfree/2019/may/29/tax-red-meatsave-the-planet-improve-health-sin-levy.

38. Bless A. Opinion: Does Australia Need a Tax on Red Meat? Sydney Environment Institute; 2018.

39. Baker P, Demaio AR. The political economy of healthy and sustainable food systems. In: Lawrence M, Friel S, eds. Healthy and Sustainable Food Systems. London, UK: Routledge; 2019.

40. The International Panel of Experts on Sustainable Food Systems (IPES-Food). Too Big to Feed: Exploring the Impacts of Mega-Mergers, Concentration, Concentration of Power in the Agri-Food Sector. IPESFood; 2017

41. Popay J, Roberts H, Sowden A, et al. Guidance on the conduct of narrative synthesis in systematic reviews. A Product from the ESRC Methods Programme. Version 1. 2006. doi:10.13140/2.1.1018.4643

42. Greenhalgh T, Thorne S, Malterud K. Time to challenge the spurious hierarchy of systematic over narrative reviews? Eur J Clin Invest. 2018;48(6):e12931. doi:10.1111/eci.12931

43. Liberati A, Altman DG, Tetzlaff J, et al. The PRISMA statement for reporting systematic reviews and meta-analyses of studies that evaluate healthcare interventions: explanation and elaboration. BMJ. 2009;339:b2700. doi:10.1136/bmj.b2700

44. Corduneanu-Huci C, Hamilton A, Ferrer IM. Understanding Policy Change: How to Apply Political Economy Concepts in Practice. World Bank Publications; 2012.

45. The International Panel of Experts on Sustainable Food Systems (IPESFood). The New Science of Sustainable Food Systems: Overcoming Barriers to Food System Reform. Brussels, Belgium: IPES-Food; 2015.

46. Harris J, Anderson M, Clément C, Nisbett N. The Political Economy of Food. London, UK: Institute of Development Studies; 2019.

47. The International Panel of Experts on Sustainable Food Systems (IPES-Food). Unravelling the Food-Health Nexus: Addressing Practices, Political Economy, and Power Relations to Build Healthier Food Systems. Brussels, Belgium: IPES-Food; 2017.

48. Hall PA. The role of interests, institutions, and ideas in the comparative political economy of the industrialized nations. In: Lichbach M, Zuckerman A, eds. Comparative Politics: Rationality, Culture, and
Structure. Cambridge, UK: Cambridge University Press; 1997:174-207.

49. Baker $P$, Brown $A D$, Wingrove $K$, et al. Generating political commitment for ending malnutrition in all its forms: a system dynamics approach for strengthening nutrition actor networks. Obes Rev. 2019;20 Suppl 2:3044. doi:10.1111/obr.12871

50. Clapp J, Fuchs DA. Corporate Power in Global Agrifood Governance. Cambridge, MA: The MIT Press; 2009.

51. Fuchs D, Di Giulio A, Glaab K, et al. Power: the missing element in sustainable consumption and absolute reductions research and action. J Clean Prod. 2016;132:298-307. doi:10.1016/j.jclepro.2015.02.006

52. Frey FW. The problem of actor designation in political analysis. Comp Polit. 1985;17(2):127-152. doi:10.2307/421726

53. Shearer JC, Abelson J, Kouyaté B, Lavis JN, Walt G. Why do policies change? institutions, interests, ideas and networks in three cases of policy reform. Health Policy Plan. 2016;31(9):1200-1211. doi:10.1093/ heapol/czw052

54. Béland D. Ideas and Policy Change: A Global Perspective. International Sociological Association, Research Committee; 2007:19.

55. Baker P, Friel S, Kay A, Baum F, Strazdins L, Mackean T. What enables and constrains the inclusion of the social determinants of health inequities in government policy agendas? a narrative review. Int $J$ Health Policy Manag. 2018;7(2):101-111. doi:10.15171/ijhpm.2017.130

56. Baker P, Friel S, Gleeson D, Thow AM, Labonte R. Trade and nutrition policy coherence: a framing analysis and Australian case study. Public Health Nutr. 2019;22(12):2329-2337. doi:10.1017/ s1368980019000752

57. Pomey MP, Morgan S, Church J, et al. Do provincial drug benefit initiatives create an effective policy lab? the evidence from Canada. $J$ Health Polit Policy Law. 2010;35(5):705-742. doi:10.1215/036168782010-025

58. Smith K. Institutional filters: the translation and re-circulation of ideas about health inequalities within policy. Policy Polit. 2013;41(1):81-100. doi:10.1332/030557312x655413

59. Béland D. Ideas, institutions, and policy change. J Eur Public Policy. 2009;16(5):701-718. doi:10.1080/13501760902983382

60. Scott WR. Institutions and Organizations: Ideas, Interests, and Identities. SAGE Publications; 2013.

61. Clapp J, Scrinis G. Big food, nutritionism, and corporate power. Globalizations. 2017;14(4):578-595. doi:10.1080/14747731.2016.123 9806

62. The International Panel of Experts on Sustainable Food Systems (IPES-Food). The New Science of Sustainable Food Systems: Overcoming Barriers to Food Systems Reform. London: IPES-Food; 2015.

63. Fuchs D. Business Power in Global Governance. Boulder, CO: Lynne Rienner Publishers; 2007.

64. Goffman E. Frame Analysis: An Essay on the Organization of Experience. Cambridge, MA: Harvard University Press; 1974.

65. Bhandari M, Busse JW, Jackowski D, et al. Association between industry funding and statistically significant pro-industry findings in medical and surgical randomized trials. CMAJ. 2004;170(4):477-480.

66. McCambridge $\mathrm{J}$, Hartwell $\mathrm{G}$. Has industry funding biased studies of the protective effects of alcohol on cardiovascular disease? a preliminary investigation of prospective cohort studies. Drug Alcohol Rev. 2015;34(1):58-66. doi:10.1111/dar.12125

67. Baker P, Hawkes C, Wingrove $\mathrm{K}$, et al. What drives political commitment for nutrition? a review and framework synthesis to inform the United Nations Decade of Action on Nutrition. BMJ Glob Health. 2018;3(1):e000485. doi:10.1136/bmjgh-2017-000485

68. Challies $\mathrm{E}$. The limits to voluntary private social standards in global agri-food system governance. Int J Sociol Agric Food. 2013;20(2):175195.

69. Henson S, Reardon T. Private agri-food standards: implications for food policy and the agri-food system. Food Policy. 2005;30(3):241253. doi:10.1016/j.foodpol.2005.05.002

70. NVivo qualitative data analysis software -- Version 122018 [computer program]. QSR International; 2018.

71. Lewis-Beck MS, Bryman A, Liao TF. The SAGE Encyclopedia of Social Science Research Methods. Thousand Oaks, Calif: Sage; 2004. doi:10.4135/9781412950589

72. Howard. PH. Corporate Concentration in Global Meat Processing: The Role of Government Subsidies. Cambridge, MA: The MIT Press; 2019. 
73. Panagiotou D. Market power effects of the livestock mandatory reporting act in the US meat industry: a stochastic frontier approach under uncertainty. J Ind Competition Trade. 2019;19(1):103-122. doi:10.1007/s10842-018-0280-9

74. Beef+Lamb New Zealand. Meat processing in New Zealand. 2019; https://beeflambnz.com/sites/default/files/Meat $\% 20$ processors $\% 20$ in\%20NZ\%20-\%20May\%202019.pdf. 2020.

75. Sexton AE, Garnett T, Lorimer J. Framing the future of food: the contested promises of alternative proteins. Environ Plan E Nat Space. 2019;2(1):47-72. doi:10.1177/2514848619827009

76. He J, Evans NM, Liu H, Shao S. A review of research on plant-based meat alternatives: driving forces, history, manufacturing, and consumer attitudes. Compr Rev Food Sci Food Saf. 2020;19(5):2639-2656. doi:10.1111/1541-4337.12610

77. Fortune A. Cargill Increases Investment in Pea Protein Business. Global Meat News; 2019.

78. Nickel R, Polansek T. Big Ag Wants a Cut of Booming Fake-Meat Market. Reuters. September 9, 2019. https://www.reuters.com/article/ us-food-meat-alternative-idUSKCN1VU11B.

79. Meat \& Livestock Australia. About MLA - The Red Meat Industry. https:// www.mla.com.au/about-mla/the-red-meat-industry/. Accessed May 10, 2019. Published 2019.

80. Bless A. Addressing the Impacts of Red Meat Consumption: Lessons from Australia's Tobacco Control Regime. Sydney, Australia: Department of Government and International Relations, University of Sydney; 2019.

81. Milman O, Leavenworth S. China's Plan to Cut Meat Consumption by $50 \%$ Cheered by Climate Campaigners. The Guardian. June 20, 2016. https://www.theguardian.com/world/2016/jun/20/chinas-meatconsumption-climate-change.

82. Food and Agriculture Organization. Livestock's Long Shadow: Environmental Issues and Options. Rome: Food and Agriculture Organization of the United Nations; 2006.

83. Intergovernmental Panel on Climate Change (IPCC). Climate change and land. Geneva, Switzerland: IPCC; 2019.

84. Legg W. Sustainable Agricultural Development for Food Security and Nutrition: What Roles for Livestock? Rome: HLPE; 2017.

85. Food and Agriculture Organization (FAO). List of Codex Committees: Active. http://www.fao.org/fao-who-codexalimentarius/committees/en/. Accessed October 28, 2020. Published 2020.

86. Abadie LM, Galarraga I, Milford AB, Gustavsen GW. Using food taxes and subsidies to achieve emission reduction targets in Norway. J Clean Prod. 2016;134(Pt A):280-297. doi:10.1016/j.jclepro.2015.09.054

87. Bähr CC. Greenhouse gas taxes on meat products: a legal perspective. Transnational Environmental Law. 2015;4(1):153-179. doi:10.1017/ s2047102515000011

88. BlandfordD, Gaasland I, VårdalE. The trade-off between food production and greenhouse gas mitigation in Norwegian agriculture. Agric Ecosyst Environ.2014;184:59-66. doi:10.1016/j.agee.2013.11.025

89. Caro D, Frederiksen $P$, Thomsen M, Pedersen AB. Toward a more consistent combined approach of reduction targets and climate policy regulations: the illustrative case of a meat tax in Denmark. Environ Sci Policy. 2017;76:78-81. doi:10.1016/j.envsci.2017.06.013

90. Chloupkova J, Svendsen GT, Zdechovsky T. A global meat tax: from big data to a double dividend. Agric Econ. 2018;64(6):256-264. doi:10.17221/270/2016-agricecon

91. Dorner Z, Kerr S. Implications of global emission policy scenarios for domestic agriculture: a New Zealand case study. Clim Policy. 2017;17(8):998-1013. doi:10.1080/14693062.2016.1215285

92. Fellmann $\mathrm{T}$, Witzke $\mathrm{P}$, Weiss $\mathrm{F}$, et al. Major challenges of integrating agriculture into climate change mitigation policy frameworks. Mitig Adapt Strateg Glob Chang. 2018;23(3):451-468. doi:10.1007/s11027017-9743-2

93. Gren IM, Moberg E, Säll S, Röös E. Design of a climate tax on food consumption: examples of tomatoes and beef in Sweden. J Clean Prod. 2019;211:1576-1585. doi:10.1016/j.jclepro.2018.11.238

94. Revell BJ. One Man's Meat ... 2050? ruminations on future meat demand in the context of global warming. J Agric Econ. 2015;66(3):573614. doi:10.1111/1477-9552.12121

95. Snowdon W, Thow AM. Trade policy and obesity prevention: challenges and innovation in the Pacific Islands. Obes Rev. 2013;14 Suppl 2:150158. doi:10.1111/obr.12090
96. Thow AM, Swinburn B, Colagiuri S, et al. Trade and food policy: case studies from three Pacific Island countries. Food Policy. 2010;35(6):556-564. doi:10.1016/j.foodpol.2010.06.005

97. Vinnari M, Tapio P. Sustainability of diets: from concepts to governance. EcolEcon. 2012;74:46-54. doi:10.1016/j.ecolecon.2011.12.012

98. Wirsenius S, Hedenus F, Mohlin K. Greenhouse gas taxes on animal food products: rationale, tax scheme and climate mitigation effects. Clim Change. 2011;108(1-2):159-184. doi:10.1007/s10584-010-9971-x

99. Taylor CR, Walsh MG, Lee C. The US/EU beef controversy and a proposed framework for resolving standards disputes in international trade. $J$ Consum Aff. 2003;37(1):101-122. doi:10.1111/j.1745-6606.2003.tb00442.x

100. Thow AM, Annan R, Mensah L, Chowdhury SN. Development, implementation and outcome of standards to restrict fatty meat in the food supply and prevent NCDs: learning from an innovative trade/food policy in Ghana. BMC Public Health. 2014;14:249. doi:10.1186/14712458-14-249

101. Reducetarian Foundation. Reducetarian - About. https://reducetarian. org/what. Published 2020.

102. Lykkeskov A, Gjerris M. The moral justification behind a climate tax on beef in Denmark. Food Ethics. 2017;1(2):181-191. doi:10.1007/ s41055-017-0017-1

103. World Wildlife Fund (WWF). Appetite for Destruction. Gland, Switzerland: WWF; 2017

104. Laestadius LI, Neff RA, Barry CL, Frattaroli S. No No meat, less meat, or better meat: understanding NGO messaging choices intended to alter meat consumption in light of climate change. Environ Commun. 2016;10(1):84-103. doi:10.1080/17524032.2014.981561

105. Laestadius LI, Neff RA, Barry CL, Frattaroli S. Meat consumption and climate change: the role of non-governmental organizations. Clim Change. 2013;120(1):25-38. doi:10.1007/s10584-013-0807-3

106. Vapnek J, Chapman MS. Legislative and Regulatory Options for Animal Welfare. Rome: Food and Agriculture Organization (FAO); 2010.

107. Torrez M. Meatless Monday: simple public health suggestion or extremist plot? J Environ Law Litig. 2013;28(3):515-544.

108. Singer R. Neoliberal backgrounding, the Meatless Monday campaign, and the rhetorical intersections of food, nature, and cultural identity. Commun Cult Crit. 2017;10(2):344-364. doi:10.1111/cccr.12155

109. Zenoff A, Sabbagh H, Mui H, Safaeinili N. The Meatless Monday Campaign in Los Angeles. https://www.publichealth.columbia. edu/sites/default/files/pdf/meatless_monday_evaluation_plan.pdf. Published December 9, 2014.

110. Graham T, Abrahamse W. Communicating the climate impacts of meat consumption: the effect of values and message framing. Glob Environ Change. 2017;44:98-108. doi:10.1016/j.gloenvcha.2017.03.004

111. Joy M. Why We Love Dogs, Eat Pigs, and Wear Cows: An Introduction to Carnism. Conari Press; 2011

112. Monteiro CA, Pfeiler TM, Patterson MD, Milburn MA. The Carnism Inventory: measuring the ideology of eating animals. Appetite. 2017;113:51-62. doi:10.1016/j.appet.2017.02.011

113. Arcari P. Normalised, human-centric discourses of meat and animals in climate change, sustainability and food security literature. Agric Human Values. 2017;34(1):69-86. doi:10.1007/s10460-016-9697-0

114. Gambert I, Linné T. From rice eaters to soy boys: race, gender, and tropes of 'plant food masculinity.' Anim Stud J. 2018;7(2):129-179.

115. Allen AM, Hof AR. Paying the price for the meat we eat. Environ Sci Policy. 2019;97:90-94. doi:10.1016/j.envsci.2019.04.010

116. Apostolidis C, McLeay F. Should we stop meating like this? reducing meat consumption through substitution. Food Policy. 2016;65:74-89. doi:10.1016/j.foodpol.2016.11.002

117. Bonnet C, Bouamra-Mechemache Z, Corre T. An environmental tax towards more sustainable food: empirical evidence of the consumption of animal products in France. Ecol Econ. 2018;147:48-61. doi:10.1016/j. ecolecon.2017.12.032

118. Brunelle T, Coat M, Viguié V. Demand-side mitigation options of the agricultural sector: potential, barriers and ways forward. OCL - Oilseeds and fats, Crops and Lipids. 2017;24(1):D104. doi:10.1051/ocl/2016051

119. de Bakker E, Dagevos H. Reducing meat consumption: ethical arguments in the context of today's consumer society. In: Global Food Security: Ethical and Legal Challenges: EurSafe 2010, Bilbao, Spain, 16-18 September 2010.

120. Stoll-Kleemann S, Schmidt UJ. Reducing meat consumption in 
developed and transition countries to counter climate change and biodiversity loss: a review of influence factors. Reg Environ Change. 2017;17(5):1261-1277. doi:10.1007/s10113-016-1057-5

121. Garnett T. Where are the best opportunities for reducing greenhouse gas emissions in the food system (including the food chain)? Food Policy. 2011;36(suppl 1):S23-S32. doi:10.1016/j.foodpol.2010.10.010

122. Hoek AC, Pearson D, James SW, Lawrence MA, Friel S. Healthy and environmentally sustainable food choices: consumer responses to point-of-purchase actions. Food Qual Prefer. 2017;58:94-106. doi:10.1016/j.foodqual.2016.12.008

123. Lang T. Meat and policy: charting a course through the complexity. In: The Meat Crisis: Developing More Sustainable and Ethical Production and Consumption. 2nd ed. Routledge; 2017:317-334.

124. Lerner H, Algers B, Gunnarsson S, Nordgren A. Stakeholders on meat production, meat consumption and mitigation of climate change: Sweden as a case. J Agric Environ Ethics. 2013;26(3):663-678. doi:10.1007/s10806-012-9420-0

125. McAlpine CA, Etter A, Fearnside PM, Seabrook L, Laurance WF. Increasing world consumption of beef as a driver of regional and global change: a call for policy action based on evidence from Queensland (Australia), Colombia and Brazil. Glob Environ Change. 2009;19(1):2133. doi:10.1016/j.gloenvcha.2008.10.008

126. Niva M, Jallinoja P. Taking a stand through food choices? Characteristics of political food consumption and consumers in Finland. Ecol Econ. 2018;154:349-360. doi:10.1016/j.ecolecon.2018.08.013

127. Poppe KJ. On markets and government: property rights to promote sustainability with market forces. NJAS - Wageningen Journal of Life Sciences. 2013;66:33-37. doi:10.1016/j.njas.2013.05.010

128. Whitley CT, Gunderson R, Charters M. Public receptiveness to policies promoting plant-based diets: framing effects and social psychological and structural influences. J Environ Policy Plan. 2018;20(1):45-63. doi :10.1080/1523908x.2017.1304817

129. Rothgerber H. Real men don't eat (vegetable) quiche: masculinity and the justification of meat consumption. Psychol Men Masc. 2013:14(4):363-375. doi:10.1037/a0030379

130. Clonan A, Roberts KE, Holdsworth M. Socioeconomic and demographic drivers of red and processed meat consumption: implications for health and environmental sustainability. Proc Nutr Soc. 2016;75(3):367-373. doi:10.1017/s0029665116000100

131. Adams CJ. The Sexual Politics of Meat: A Feminist-Vegetarian Critical Theory. USA: Bloomsbury Publishing; 2015.

132. Upton's Naturals Co. and the Plant Based Foods Association VERSUS Phil Bryant MS. Complaint for Declaratory and Injunctive Relief. Vol Civil Action No. 3:19-cv-462-HTW-LRA2019. https://ij.org/wp-content/ uploads/2019/07/Uptons-Naturals-Co.-et-al.-v.-Phil-Bryant-et-al.Complaint-for-Declaratory-and-Injunctive-Relief 7.1.2019.pdf.

133. Watson E. PBFA and Upton's Naturals Challenge Mississippi Law Restricting Plant-Based and Cell-Cultured 'Meat' Labelling. Food Navigator-USA; 2019.

134. Watson E. PBFA, Upton's Naturals Drop Lawsuit as Mississippi Revises Plant-Based Meat Labeling Law: 'This is a Total Victory.' Food Navigator-USA: 2019.

135. Daly JG. Reducing meat and dairy consumption: a cultural change approach. International Journal of Environmental, Cultural, Economic and Social Sustainability. 2011;7(2):223-234.

136. Kunst JR, Hohle SM. Meat eaters by dissociation: how we present, prepare and talk about meat increases willingness to eat meat by reducing empathy and disgust. Appetite. 2016;105:758-774. doi:10.1016/j.appet.2016.07.009

137. Mann D, Thornton L, Crawford D, Ball K. Australian consumers' views towards an environmentally sustainable eating pattern. Public Health Nutr. 2018;21(14):2714-2722. doi:10.1017/s1368980018001192

138. GRAIN, Institute for Agriculture and Trade Policy (IATP). Emissions Impossible: How Big Meat and Dairy Are Heating Up the Planet. GRAIN, Institute for Agriculture and Trade Policy (IATP); 2018.

139. Meat \& Livestock Australia. MLA Global Consumer Tracker Australia. https://www.mla.com.au/globalassets/mla-corporate/prices--markets/ documents/os-markets/red-meat-market-snapshots/2019/mla-msaustralia-beef-sheep-2019.pdf. Accessed February 2020. Published 2019.

140. Clapp J. Financialization, distance and global food politics. J Peasant Stud. 2014;41(5):797-814. doi:10.1080/03066150.2013.875536

141. McMichael P. A food regime genealogy. J Peasant Stud. 2009;
36(1):139-169. doi:10.1080/03066150902820354

142. Lang $T$, Barling D. Food security and food sustainability: reformulating the debate. Geogr J. 2012;178(4):313-326. doi:10.1111/j.14754959.2012.00480.x

143. Evans N, Morris C, Winter M. Conceptualizing agriculture: a critique of post-productivism as the new orthodoxy. Prog Hum Geogr. 2002; 26(3):313-332. doi:10.1191/0309132502ph372ra

144. Lawrence G, Richards C, Lyons K. Food security in Australia in an era of neoliberalism, productivism and climate change. J Rural Stud. 2013;29:30-39. doi:10.1016/j.jrurstud.2011.12.005

145. Australian Government Department of Agriculture, Water and the Environment. Red meat livestock industry structure. https://www. agriculture.gov.au/ag-farm-food/meat-wool-dairy/red-meat-livestock/ facts. Published 2020.

146. The Food and Land Use Coalition. The Global Consultation Report of the Food and Land Use Coalition. The Food and Land Use Coalition; 2019.

147. The Physicians Committee for Responsible Medicine. Taxing America's Health: Subsidies for Meat and Dairy Products. https:// archive.vn/20130415140347/http://www.pcrm.org/search/?cid=2586. Accessed February 28, 2020. Published 2011.

148. Schram A, Ruckert A, VanDuzer JA, et al. A conceptual framework for investigating the impacts of international trade and investment agreements on noncommunicable disease risk factors. Health Policy Plan. 2018;33(1):123-136. doi:10.1093/heapol/czx133

149. Clark SE, Hawkes C, Murphy SM, Hansen-Kuhn KA, Wallinga D. Exporting obesity: US farm and trade policy and the transformation of the Mexican consumer food environment. Int J Occup Environ Health. 2012;18(1):53-65. doi:10.1179/1077352512z.0000000007

150. Friel S, Gleeson D, Thow AM, et al. A new generation of trade policy: potential risks to diet-related health from the trans pacific partnership agreement. Global Health. 2013;9:46. doi:10.1186/1744-8603-9-46

151. Reisch L, Eberle U, Lorek S. Sustainable food consumption: an overview of contemporary issues and policies. Sustainability: Science, Practice and Policy. 2013;9(2):7-25. doi:10.1080/15487733.2013.119 08111

152. White RR, Brady M. Can consumers' willingness to pay incentivize adoption of environmental impact reducing technologies in meat animal production? Food Policy. 2014;49(Pt 1):41-49. doi:10.1016/j. foodpol.2014.06.007

153. Springmann M, Clark M, Mason-D'Croz D, et al. Options for keeping the food system within environmental limits. Nature. 2018;562(7728):519525. doi:10.1038/s41586-018-0594-0

154. Parker C, Haines F. An ecological approach to regulatory studies? J Law Soc. 2018;45(1):136-155. doi:10.1111/jols.12083

155. Parker $C$, Haines $F$, Boehm $L$. The promise of ecological regulation: the case of intensive meat. Jurimetrics. 2018;59:15-42.

156. Stuckler D, Nestle M. Big food, food systems, and global health. PLoS Med. 2012;9(6):e1001242. doi:10.1371/journal.pmed.1001242

157. Monteiro CA, Moubarac JC, Cannon G, Ng SW, Popkin B. Ultraprocessed products are becoming dominant in the global food system. Obes Rev. 2013;14 Suppl 2:21-28. doi:10.1111/obr.12107

158. Food and Agriculture Organization. FAO's role in animal production. http://www.fao.org/animal-production/en/. Accessed February 28, 2020.

159. Kelloway C, Miller S. Food and Power: Addressing Monopolization in America's Food System. Washington, DC: Open Markets Institute; 2019.

160. Keogh M. "There's a Major Beef Over Dietary Guidelines". The Sydney Morning Herald; 2011.

161. The Physicians Committee for Responsible Medicine. National Pork Producers Council Annual Lobbying Totals: 1998-2019. https://www. opensecrets.org/orgs/lobbying?id=D000000676. Published 2020.

162. Corkery M, Yaffe-Bellany D, Swanson A. Powerful Meat Industry Holds More Sway After Trump's Order. New York Times. April 29, 2020. https://www.nytimes.com/2020/04/29/business/coronavirus-trumpmeat-plants.html.

163. Wilde P, Pomeranz JL, Lizewski LJ, Ruan M, Mozaffarian D, Zhang FF. Legal feasibility of US government policies to reduce cancer risk by reducing intake of processed meat. Milbank Q. 2019;97(2):420-448. doi:10.1111/1468-0009.12385

164. de Area Leão Pereira EJ, de Santana Ribeiro LC, da Silva Freitas LF, de Barros Pereira HB. Brazilian policy and agribusiness damage the 
Amazon rainforest. Land Use Policy. 2020;92:104491. doi:10.1016/j. landusepol.2020.104491

165. Almiron N, Zoppeddu M. Eating meat and climate change: the media blind spot--a study of Spanish and italian press coverage. Environ Commun. 2015;9(3):307-325. doi:10.1080/17524032.2014.953968

166. Pohjolainen $P$, Tapio $P$, Vinnari M, Jokinen $P$, Räsänen P. Consumer consciousness on meat and the environment - Exploring differences. Appetite. 2016;101:37-45. doi:10.1016/j.appet.2016.02.012

167. Buddle EA, Bray HJ, Ankeny RA. Why would we believe them? meat consumers' reactions to online farm animal welfare activism in Australia. Communication Research and Practice. 2018;4(3):246-260. doi:10.1080/22041451.2018.1451209

168. Cole M. Getting (Green) Beef: Anti-Vegan Rhetoric and the Legitimizing of Eco-Friendly Oppression. In: Critical Animal and Media Studies. Routledge; 2015:121-137.

169. Bruce A. The lore of low methane livestock: co-producing technology and animals for reduced climate change impact. Life Sci Soc Policy. 2013;9(1):10. doi:10.1186/2195-7819-9-10

170. Lacy-Nichols J, Scrinis G, Carey R. The politics of voluntary selfregulation: insights from the development and promotion of the Australian Beverages Council's Commitment. Public Health Nutr. 2020;23(3):564-575. doi:10.1017/s1368980019002003

171. Herzog HJ. Why We Can't Reverse Climate Change with 'Negative Emissions' Technologies. The Conversation. October 9, 2018. https:// theconversation.com/why-we-cant-reverse-climate-change-withnegative-emissions-technologies-103504.

172. Hedenus F, Wirsenius S, Johansson DJA. The importance of reduced meat and dairy consumption for meeting stringent climate change targets. Clim Change. 2014;124(1):79-91. doi:10.1007/s10584-0141104-5

173. Sonoda $Y$, Oishi K, Chomei Y, Hirooka H. How do human values influence the beef preferences of consumer segments regarding animal welfare and environmentally friendly production? Meat Sci. 2018;146:75-86. doi:10.1016/j.meatsci.2018.07.030

174. Van Loo EJ, Hoefkens C, Verbeke W. Healthy, sustainable and plantbased eating: perceived (mis) match and involvement-based consumer segments as targets for future policy. Food Policy. 2017; 69:46-57. doi:10.1016/j.foodpol.2017.03.001

175. Parker C, Carey R, Scrinis G. The consumer labelling turn in farmed animal welfare politics: from the margins of animal advocacy to mainstream supermarket shelves. In: Phillipov M, Kirkwood K, eds. Alternative Food Politics: From the Margins to the Mainstream. Routledge (Critical Food Series, 2018); 2017.

176. Ilea RC. Intensive livestock farming: global trends, increased environmental concerns, and ethical solutions. J Agric Environ Ethics. 2009;22(2):153-167. doi:10.1007/s10806-008-9136-3

177. Magnusson RS. Obesity prevention and personal responsibility: the case of front-of-pack food labelling in Australia. BMC Public Health. 2010;10:662. doi:10.1186/1471-2458-10-662

178. Mason P, Lang T. Sustainable Diets: How Ecological Nutrition Can Transform Consumption and the Food System. Taylor \& Francis; 2017.

179. International Agency for Research on Cancer (IARC). Red Meat and Processed Meat: IARC Monographs on the Evaluation of Carcinogenic Risks to Humans. Lyon, France: IARC; 2018.

180. Roussell MA, Hill AM, Gaugler TL, et al. Beef in an Optimal Lean Diet study: effects on lipids, lipoproteins, and apolipoproteins. Am J Clin Nutr. 2012;95(1):9-16. doi:10.3945/ajcn.111.016261

181. Dixon J, Sindall C, Banwell C. Exploring the intersectoral partnerships guiding Australia's dietary advice. Health Promot Int. 2004;19(1):5-13. doi:10.1093/heapro/dah102

182. Steele S, Ruskin G, Stuckler D. Pushing partnerships: corporate influence on research and policy via the International Life Sciences Institute. Public Health Nutr. 2020;23(11):2032-2040. doi:10.1017/ s1368980019005184

183. Zeraatkar D, Johnston BC, Bartoszko J, et al. Effect of lower versus higher red meat intake on cardiometabolic and cancer outcomes: a systematic review of randomized trials. Ann Intern Med. 2019; 171(10):721-731. doi:10.7326/m19-0622

184. Johnston BC, Zeraatkar D, Han MA, et al. Unprocessed red meat and processed meat consumption: dietary guideline recommendations from the Nutritional Recommendations (NutriRECS) Consortium. Ann Intern Med. 2019;171(10):756-764. doi:10.7326/m19-1621
185. Bero L. When Big Companies Fund Academic Research, The Truth Often Comes Last. The Conversation. October 2, 2019. https:// theconversation.com/when-big-companies-fund-academic-researchthe-truth-often-comes-last-119164.

186. Carolan M. The Real Cost of Cheap Food. Routledge; 2013.

187. Ferrante L, Fearnside PM. Brazil's new president and 'ruralists' threaten Amazonia's environment, traditional peoples and the global climate. Environ Conserv. 2019;46(4):261-263. doi:10.1017/ s0376892919000213

188. de Boer J, Aiking H. Strategies towards healthy and sustainable protein consumption: a transition framework at the levels of diets, dishes, and dish ingredients. Food Qual Prefer. 2019;73:171-181. doi:10.1016/j. foodqual.2018.11.012

189. Hospes O, Brons, A. Food systems governance: a systematic literature review. In: Kennedy A, Liljeblad J, eds. Food Systems Governance: Challenges for Justice, Equality and Human Rights. Taylor \& Francis Group; 2016.

190. Chapman S. Public Health Advocacy and Tobacco Control: Making Smoking History. John Wiley \& Sons; 2008.

191. Chang KM, Hess JJ, Balbus JM, et al. Ancillary health effects of climate mitigation scenarios as drivers of policy uptake: a review of air quality, transportation and diet co-benefits modeling studies. Environ Res Lett. 2017;12(11):113001. doi:10.1088/1748-9326/aa8f7b

192. Farchi S, De Sario M, Lapucci E, Davoli M, Michelozzi P. Meat consumption reduction in Italian regions: health co-benefits and decreases in GHG emissions. PLoS One. 2017;12(8):e0182960. doi:10.1371/journal. pone. 0182960

193. Hyland JJ, Henchion M, McCarthy M, McCarthy SN. The role of meat in strategies to achieve a sustainable diet lower in greenhouse gas emissions: a review. Meat Sci. 2017;132:189-195. doi:10.1016/j. meatsci.2017.04.014

194. Virah-Sawmy M, Durán AP, Green JMH, Guerrero AM, Biggs D, West CD. Sustainability gridlock in a global agricultural commodity chain: reframing the soy-meat food system. Sustain Prod Consum. 2019;18:210-223. doi:10.1016/j.spc.2019.01.003

195. Bryngelsson D, Wirsenius S, Hedenus F, Sonesson U. How can the EU climate targets be met? a combined analysis of technological and demand-side changes in food and agriculture. Food Policy. 2016;59:152-164. doi:10.1016/j.foodpol.2015.12.012

196. da Costa NB Jr, Baldissera TC, Pinto CE, Garagorry FC, de Moraes A, de Faccio Carvalho PC. Public policies for low carbon emission agriculture foster beef cattle production in southern Brazil. Land Use Policy. 2019;80:269-273. doi:10.1016/j.landusepol.2018.10.014

197. Delgado C, Rosegrant M, Steinfeld H, Ehui S, Courbois C. Livestock to 2020: the next food revolution. In: Pinstrup-Andersen P, PandyaLorch R, eds. The Unfinished Agenda: Perspectives on Overcoming Hunger, Poverty, and Environmental Degradation. Washington, DC: International Food Policy Research Institute; 2001.

198. Du Y, Ge Y, Ren Y, et al. A global strategy to mitigate the environmental impact of China's ruminant consumption boom. Nat Commun. 2018;9(1):4133. doi:10.1038/s41467-018-06381-0

199. Evans N, Gaskell P, Winter M. Re-assessing agrarian policy and practice in local environmental management: the case of beef cattle. Land Use Policy. 2003;20(3):231-242. doi:10.1016/S02648377(03)00026-7

200. Friel S, Dangour AD, Garnett T, et al. Public health benefits of strategies to reduce greenhouse-gas emissions: food and agriculture. Lancet. 2009;374(9706):2016-2025. doi:10.1016/s0140-6736(09)61753-0

201. Garnett T. Livestock-related greenhouse gas emissions: impacts and options for policy makers. Environm Sci Policy. 2009;12(4):491-503. doi:10.1016/j.envsci.2009.01.006

202. Gerber PJ, Steinfeld H. Global environmental consequences of the livestock sector's growth. Outlook Agric. 2008;37(1):7-13. doi: $10.5367 / 000000008783883555$

203. Gerber PJ, Vellinga TV, Steinfeld H. Issues and options in addressing the environmental consequences of livestock sector's growth. Meat Sci. 2010;84(2):244-247. doi:10.1016/j.meatsci.2009.10.016

204. Kumm KI. Towards sustainable Swedish agriculture. J Sustain Agric. 2001;18(4):27-37. doi:10.1300/J064v18n04_05

205. Leifeld J, Fuhrer J. Greenhouse gas emissions from Swiss agriculture since 1990: implications for environmental policies to mitigate global warming. Environ Sci Policy. 2005;8(4):410-417. doi:10.1016/j. 
envsci.2005.04.001

206. Mosnier C, Duclos A, Agabriel J, Gac A. What prospective scenarios for 2035 will be compatible with reduced impact of French beef and dairy farm on climate change? Agric Syst. 2017;157:193-201. doi:10.1016/j. agsy.2017.07.006

207. Rivera-Ferre MG, López-i-Gelats F, Howden M, Smith P, Morton JF, Herrero M. Re-framing the climate change debate in the livestock sector: mitigation and adaptation options. Wiley Interdiscip Rev Clim Change. 2016;7(6):869-892. doi:10.1002/wcc.421

208. Röös E, Bajželj B, Smith P, Patel M, Little D, Garnett T. Greedy or needy? land use and climate impacts of food in 2050 under different livestock futures. Glob Environ Change. 2017;47:1-12. doi:10.1016/j. gloenvcha.2017.09.001

209. Santos R, Antunes P, Baptista G, Mateus P, Madruga L. Stakeholder participation in the design of environmental policy mixes. Ecol Econ. 2006;60(1):100-110. doi:10.1016/j.ecolecon.2005.11.025

210. Sarkwa FO, Timpong-Jones EC, Assuming-Bediako N, Aikins S, Adogla-Bessa T. The contribution of livestock production to climate change: a review. Livest Res Rural Dev. 2016;28(3):Article 37.

211. Singh V, Rastogi A, Nautiyal N, Negi V. Livestock and climate change: the key actors and the sufferers of global warming. Indian J Anim Sci. 2017;87(1):11-20.

212. Stevanović M, Popp A, Bodirsky BL, et al. Mitigation strategies for greenhouse gas emissions from agriculture and land-use change: consequences for food prices. Environ Sci Technol. 2017;51(1):365374. doi:10.1021/acs.est.6b04291

213. Tessema WK, Ingenbleek PTM, van Trijp HCM. Pastoralism, sustainability, and marketing. A review. Agron Sustain Dev. 2014; 34(1):75-92. doi:10.1007/s13593-013-0167-4

214. Tilman D, Clark M. Food, agriculture \& the environment: can we feed the world \& save the earth? Daedalus. 2015;144(4):8-23. doi:10.1162/ DAED_a_00350

215. Williams JE, Price RJ. Impacts of red meat production on biodiversity in Australia: a review and comparison with alternative protein production industries. Anim Prod Sci. 2010;50(8):723-747. doi:10.1071/an09132

216. Bowles N, Alexander S, Hadjikakou M. The livestock sector and planetary boundaries: a 'limits to growth' perspective with dietary implications. Ecol Econ. 2019;160:128-136. doi:10.1016/j. ecolecon.2019.01.033

217. Cederberg C, Hedenus F, Wirsenius S, Sonesson U. Trends in greenhouse gas emissions from consumption and production of animal food products - implications for long-term climate targets. Animal. 2013;7(2):330-340. doi:10.1017/s1751731112001498

218. Henderson B, Golub A, Pambudi D, et al. The power and pain of market-based carbon policies: a global application to greenhouse gases from ruminant livestock production. Mitig Adapt Strateg Glob Chang. 2018;23(3):349-369. doi:10.1007/s11027-017-9737-0

219. Moran D, Wall E. Livestock production and greenhouse gas emissions: defining the problem and specifying solutions. Anim Front. 2011;1(1):19-25. doi:10.2527/af.2011-0012

220. Revell B. Meat and Milk Consumption 2050: the Potential for Demandside Solutions to Greenhouse Gas Emissions Reduction. EuroChoices. 2015;14(3):4-11. doi:10.1111/1746-692X.12103

221. Sarlio S. "Serving sustainable and healthy food to consumers and decision makers": from commitments to action. In: Sarlio S, ed. Towards Healthy and Sustainable Diets: Perspectives and Policy to Promote the Health of People and the Planet. Cham: Springer; 2018:63-82. doi:10.1007/978-3-319-74204-5_4

222. Springmann M, Mason-D'Croz D, Robinson S, et al. Mitigation potential and global health impacts from emissions pricing of food commodities. Nat Clim Chang. 2017;7(1):69-74. doi:10.1038/nclimate3155

223. Snowdon W, Moodie M, Schultz J, Swinburn B. Modelling of potential food policy interventions in Fiji and Tonga and their impacts on noncommunicable disease mortality. Food Policy. 2011;36(5):597-605. doi:10.1016/j.foodpol.2011.06.001

224. Galaz V, Crona B, Dauriach A, Jouffray J-B, Österblom H, Fichtner J. Tax havens and global environmental degradation. Nat Ecol Evol. 2018;2(9):1352-1357. doi:10.1038/s41559-018-0497-3

225. Edjabou LD, Smed S. The effect of using consumption taxes on foods to promote climate friendly diets - the case of Denmark. Food Policy. 2013;39:84-96. doi:10.1016/j.foodpol.2012.12.004

226. Hahn WF, Davis CG. Costs of taxing sodium: a lunch meat application. Int Food Agribus Manag Rev. 2014;17(Special Issue A):25-39. doi:10.22004/ag.econ.164596

227. Peñalvo JL, Cudhea $F$, Micha $R$, et al. The potential impact of food taxes and subsidies on cardiovascular disease and diabetes burden and disparities in the United States. BMC Med. 2017;15(1):208. doi:10.1186/s12916-017-0971-9

228. Pitt $A$, Bendavid $E$. Effect of meat price on race and gender disparities in obesity, mortality and quality of life in the US: a model-based analysis. PLoS One. 2017;12(1):e0168710. doi:10.1371/journal.pone.0168710

229. Säll S, Gren IM. Effects of an environmental tax on meat and dairy consumption in Sweden. Food Policy. 2015;55:41-53. doi:10.1016/j. foodpol.2015.05.008

230. Schmidhuber J. The growing global obesity problem: Some policy options to address it. eJADE - Electronic Journal of Agricultural and Development Economics. 2004;1(2):272-290.

231. Schönbach JK, Thiele S, Lhachimi SK. What are the potential preventive population-health effects of a tax on processed meat? a quantitative health impact assessment for Germany. Prev Med. 2019; 118:325-331. doi:10.1016/j.ypmed.2018.11.011

232. Springmann M, Mason-D'Croz D, Robinson S, et al. Healthmotivated taxes on red and processed meat: a modelling study on optimal tax levels and associated health impacts. PLoS One. 2018; 13(11):e0204139. doi:10.1371/journal.pone.0204139

233. Vázquez-Rowe I, Larrea-Gallegos G, Villanueva-Rey P, Gilardino A. Climate change mitigation opportunities based on carbon footprint estimates of dietary patterns in Peru. PLoS One. 2017; 12(11):e0188182. doi:10.1371/journal.pone. 0188182

234. Markandya A, Galarraga I, Abadie LM, Lucas J, Spadaro JV. What role can taxes and subsidies play in changing diets? Finanzarchiv. 2016;72(2):175-210. doi:10.1628/001522116x14581329755499

235. Grebitus C, Steiner B, Veeman MM. Paying for sustainability: a cross-cultural analysis of consumers' valuations of food and non-food products labeled for carbon and water footprints. J Behav Exp Econ. 2016;63:50-58. doi:10.1016/j.socec.2016.05.003

236. Röös $E$, Ekelund L, Tjärnemo $H$. Communicating the environmental impact of meat production: challenges in the development of a Swedish meat guide. J Clean Prod. 2014;73:154-164. doi:10.1016/j. jclepro.2013.10.037

237. Bonny SPF, Gardner GE, Pethick DW, Hocquette JF. What is artificial meat and what does it mean for the future of the meat industry? $\mathrm{J}$ Integr Agric. 2015;14(2):255-263. doi:10.1016/s2095-3119(14)60888-1

238. de Bakker E, Dagevos H. Reducing meat consumption in today's consumer society: questioning the citizen-consumer gap. J Agric Environ Ethics. 2012;25(6):877-894. doi:10.1007/s10806-011-9345-z

239. Schmidinger K, Bogueva D, Marinova D. New meat without Livestock. In: Handbook of Research on Social Marketing and Its Influence on Animal Origin Food Product Consumptio. Hershey, PA: IGI Global; 2018:344-361.

240. Kurz V. Nudging to reduce meat consumption: immediate and persistent effects of an intervention at a university restaurant. J Environ Econ Manage. 2018;90:317-341. doi:10.1016/j.jeem.2018.06.005

241. Hanson EC. Successful Qualitative Health Research: A Practical Introduction. Sydney, Australia: Allen \& Unwin; 2006.

242. Attride-Stirling J. Thematic networks: an analytic tool for qualitative research. Qual Res. 2001;1(3):385-405. doi:10.1177/146879410100100307 